\title{
Connessioni e stratificazioni della forma urbana. Le tracce degli anfiteatri romani e le loro risignificazioni
}

Gian Marco Girgenti

Claudia Tarantino

Abstract

Partendo dal rilievo delle vestigia dell'anfiteatro romano di Termini Imerese e considerando sia la sua riconfigurazione virtuale che le vicende architettoniche che hanno visto il succedersi di diverse stratificazioni e ri-significazioni urbane, abbiamo concentrato il nostro interesse sulle casistiche che hanno determinato le mutazioni di forma e le sedimentazioni archeologiche di alcuni anfiteatri in Italia e in Europa. Da queste operazioni preliminari si è svolto il lavoro d'indagine su Palermo, volendo verificare - attraverso il rilievo e il ridisegno del tessuto urbano - la compatibilità delle più recenti ipotesi di localizzazione degli edifici per spettacoli nella Panormus d'età romana.
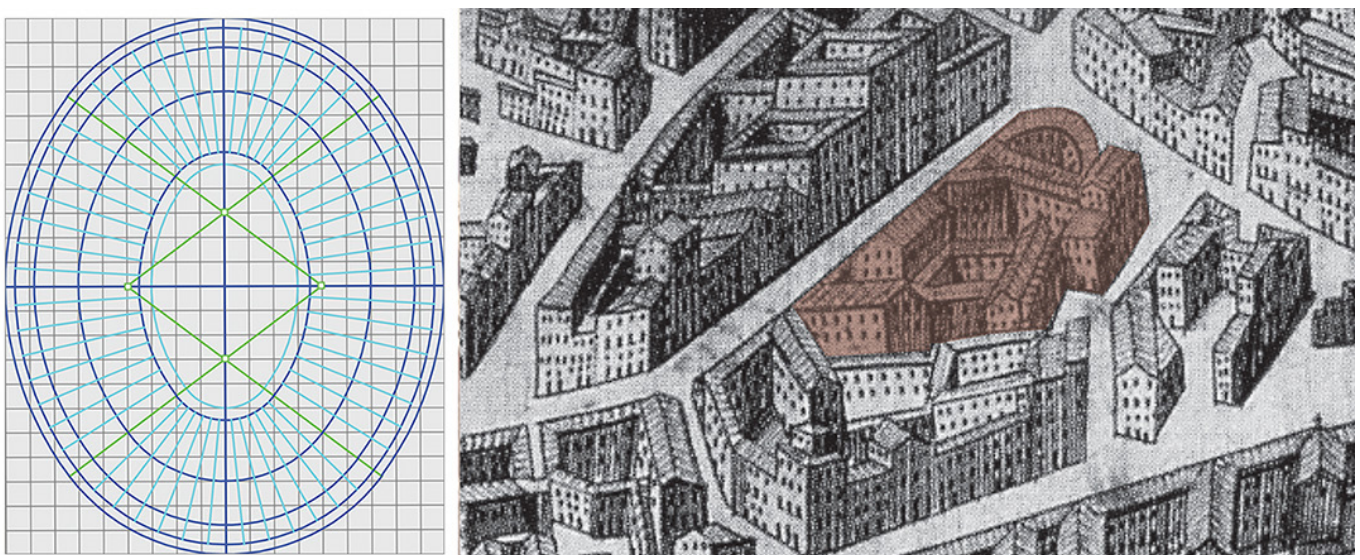


\section{Introduzione}

In merito alle riflessioni sulla forma urbis della città di Palermo nella sua versione pre-rinascimentale è da rilevare, come tendenza generalizzata, un sovradimensionamento del contributo offerto durante il periodo della dominazione islamica (IX-XII sec.) rispetto a quello della dominazione romana (III sec a.C.- V sec. d.C.). Le tracce architettoniche superstiti sono scarse per entrambi i periodi, eppure il mito della Balarm saracena, vuoi per l'indubbia fascinazione 'esotica', vuoi per la spinta data dagli studi arabistici - da Amari in poi - è più forte e insistente di quello della Panormus d'età repubblicana e imperiale. Si è abbastanza concordi nell'attribuzione alla dinastia aghlabide delle prime espansioni urbanistiche extra-moenia, continuate con i Fatimiti e i Kalbiti.

Dando quasi per assodata una sostanziale inerzia protrattasi lungo tutto l'arco della dominazione bizantina, permane l'interrogativo sul ruolo svolto dall'architettura e dall'urbanistica romane nello spazio di circa sette secoli, dopo la presa a opera degli stessi della Zyz punica nel 254 a.C.

Poche sono le notizie riguardo l'immagine della urbs del tempo, anche se non mancano le fonti documentarie e gli studi in merito. L'idea generale che viene tramandata sta nella definizione di 'città punico-romana' come se la romanitas palermitana si fosse insediata nel precedente impianto fenicio senza sostanziali alterazioni o trasformazioni dello stesso. Tra le prospezioni archeologiche più recenti è di notevole interesse il rinvenimento e la messa in luce dell'insula di piazza Sett'Angeli, con i resti di una domus pavimentata con mosaici a motivi geometrici pari per rilevanza e fattura alla villa di piazza Vittoria [Spatafora 2000]. L'impressione che ci sia ancora parecchio da rinvenire è forte, soprattutto in merito alle iniziative edificatorie che più hanno caratterizzato le città romane ovunque esse si fossero insediate, dalle opere pubbliche come strade e acquedotti agli spazi monumentali come fori, teatri e anfiteatri. II compendio più aggiornato di studi sulla Sicilia romana, pubblicato nel 2018 a cura di Oscar Belvedere e Johannes Bergemann, offre una panoramica completa ed esaustiva su molte città siciliane: spicca però, per assenza, l'interesse dedicato a
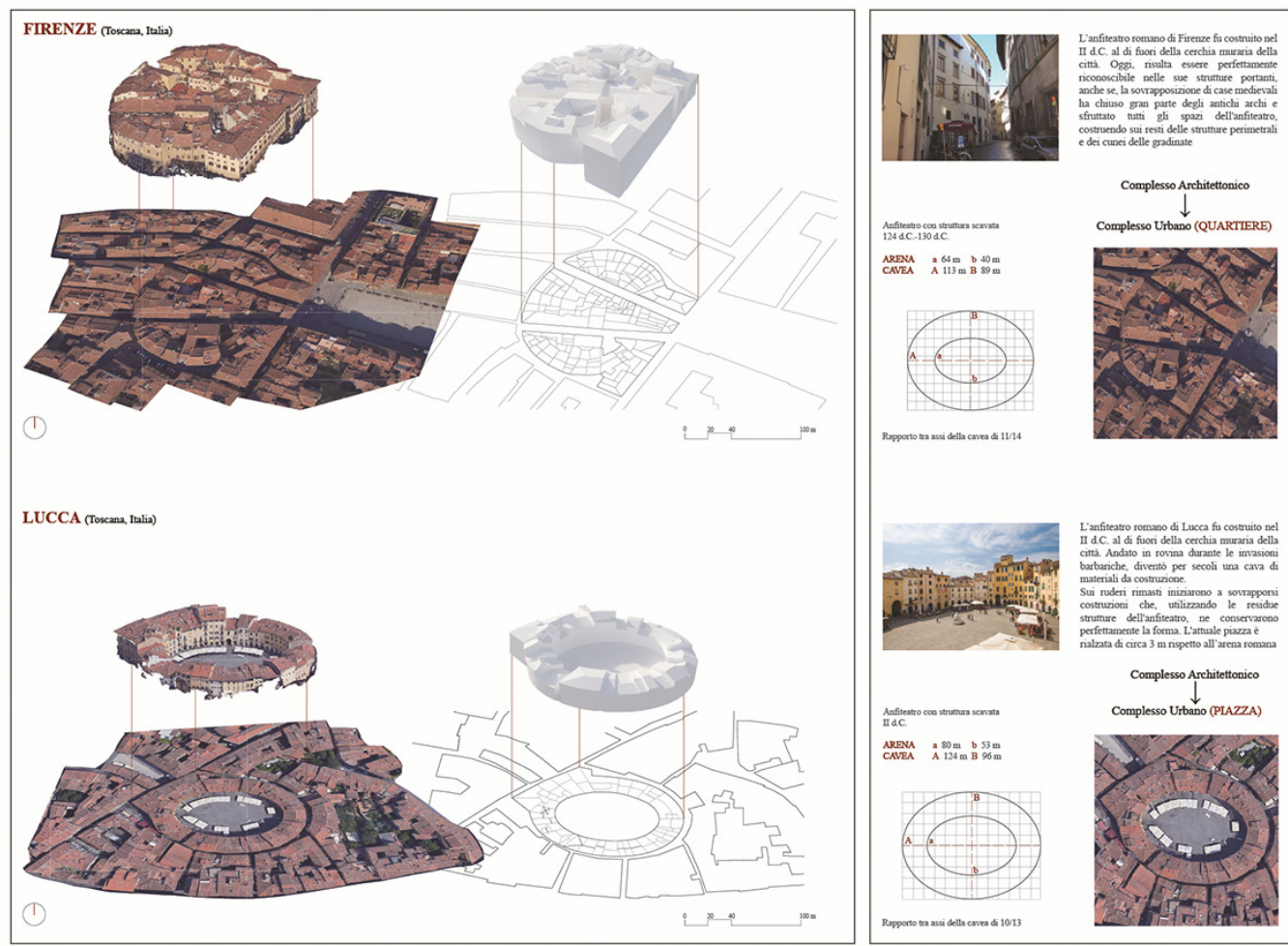
Panormus, città di primo piano e di indubbio rilievo, come testimoniato del resto dal suo puntuale inserimento sia nell'|tinerarium Antonini che nella Tabula Peutingeriana.

Particolarmente interessante, per gli ambiti dello studio che qui proponiamo, è il saggio di Daniele Malfitana e Antonino Mazzaglia a proposito dell'Anfiteatro di Catania, nel quadro di un progetto di 'Archeologia globale multidisciplinare' denominato 'OpenCiTy', aperto a competenze che vanno oltre la specificità degli studi archeologici (e della loro necessaria concentrazione e frammentarietà) e che coinvolge sguardi e operatività che potrebbero offrire, con modalità e metodologie diverse e integrate, un "piano della conoscenza" aperto al pubblico e in costante aggiornamento e sviluppo. Le conoscenze e le relative scoperte su Catania, che hanno interessato in successione il rinvenimento del Teatro, dell'Odeon e dell'Anfiteatro, sono in questo caso un esempio abbastanza pertinente di sapere in fieri e in costante sviluppo.

Sulla stessa direzione sembra muoversi Paolo Storchi che, per l'identificazione e l'individuazione di edifici mai rinvenuti né localizzati ma della cui esistenza si era pressoché certi, propone un metodo di lavoro che anticipa la possibilità della campagna di scavi con una riflessione incrociata tra l'analisi della morfologia della città e lo studio attento delle immagini satellitari telerilevate, in cerca di tracce o anomalie del tessuto urbano come possibile 'spia' di presenze più antiche. Per la peculiarità della loro conformazione e la rigida applicazione modulare delle geometrie della pianta il giovane studioso ha finora concentrato l'obiettivo delle sue ricerche sugli edifici per lo spettacolo, in special modo gli anfiteatri, offrendo ipotesi di localizzazione che, in un caso su tre (Reggio Emilia) si sono rivelate esatte. Tra le sue ipotesi di localizzazione c'è anche Palermo, ed è a partire dai suoi suggerimenti che abbiamo provato a sviluppare un possibile ragionamento sulla forma e l'evoluzione del capoluogo siciliano in età romana in relazione alle informazioni dedotte dall'analisi della topografia antica.
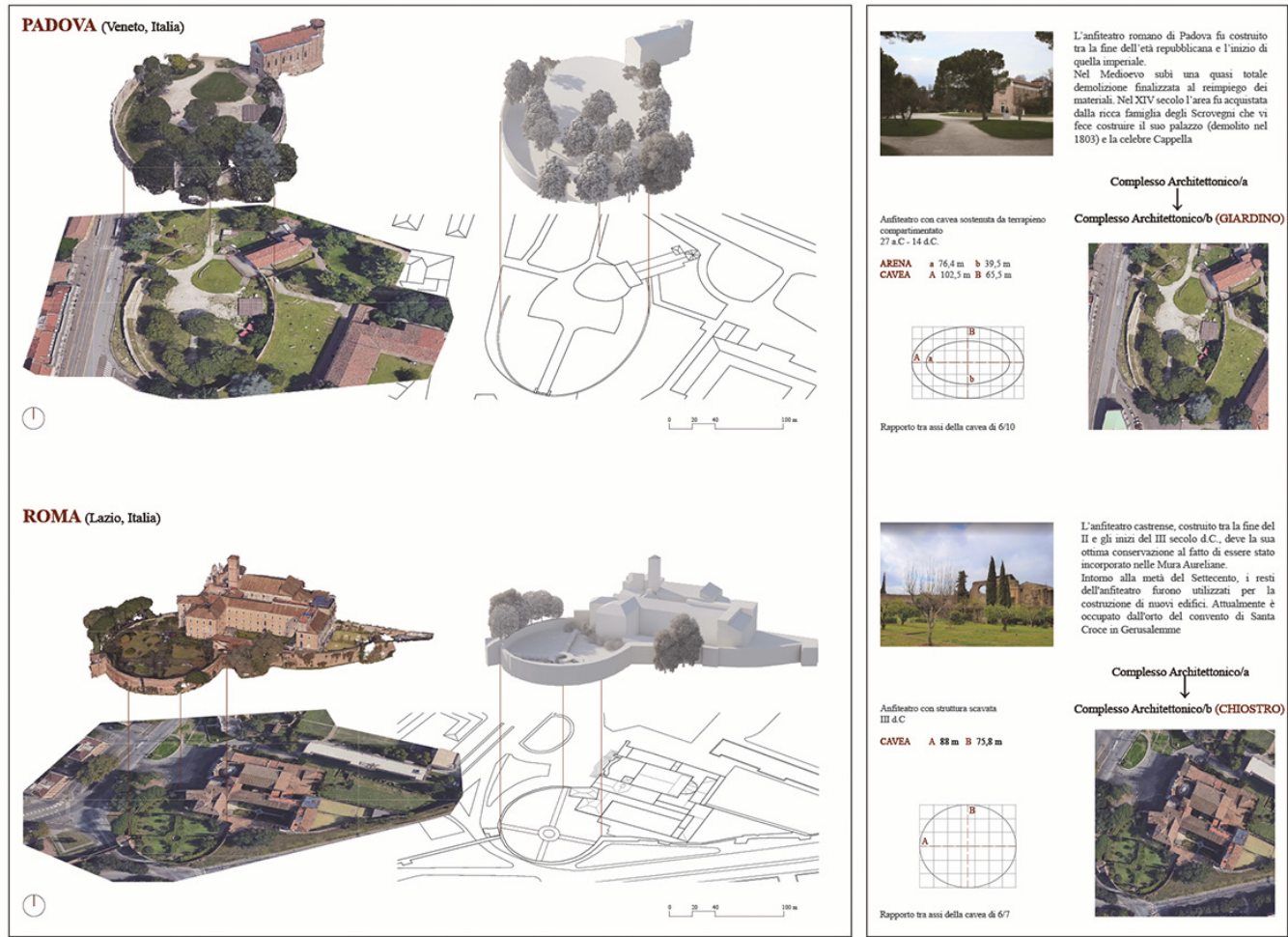


\section{Le ipotesi di localizzazione dell'anfiteatro a Palermo}

Della presenza di un anfiteatro a Palermo, costruito in pietra e in linea con le realizzazioni similari siciliane (Catania, Termini Imerese) si è praticamente certi. L'aspetto forse più interessante dell'ipotesi di Storchi riguarda la sua possibile localizzazione, nell'area compresa tra piazza San Domenico e il rione dell'Olivella. La zona, collocata nel quadro della topografia antica, è esterna al perimetro delle mura e pochissimo (se non per nulla) urbanizzata: limitrofa al Porto e al Castello a mare (il Castrum Inferius) potrebbe essere l'area d'elezione più appropriata per l'impianto di un edificio per spettacoli gladiatorii e venationes, che avrebbero richiesto spazi accessori e edifici collegati (come i ludi, palestre e caserme) difficilmente realizzabili all'interno di una città già definita nel suo sviluppo e nel suo perimetro dallo schema ippodameo di Paleapoli e Neapoli. La stessa area avrebbe potuto accogliere, nelle sue immediate adiacenze, la realizzazione di un'opera più imponente e monumentale come un circo per corse equestri (citato espressamente da John H. Humphrey seguendo la lettera della Descriptio Totius Mundi di età giustinianea). Sempre Storchi avanza più che leciti dubbi tra l'accostamento della Sala Viridis sul Piano del Palazzo a quello che avrebbe potuto essere ilTeatro, lanciando quindi la sfida a un ampliamento d'orizzonte per le ricerche sulla possibile localizzazione anche di questo.

II contributo che possiamo offrire noi, in sinergia con le brillanti intuizioni di Storchi, può riguardare l'approfondimento relativo al rilievo e alla conseguente modellazione tridimensionale, a scala urbana e quindi architettonica e di dettaglio, e il trasferimento dei dati in piattaforme di comunicazione visiva sulla scorta dell'esperienza catanese di 'Open CiTy'. Il punto di partenza delle nostre indagini, dopo la ricognizione delle planimetrie catastali e il sopralluogo in situ, è stato il vicolo San Basilio tra la via San Basilio e la via Monteleone: è una stradina stretta e tortuosa che può essere suddivisa in due tronconi, uno rettilineo l'altro curvilineo, e che media le diverse altimetrie tra le due strade con una piattaforma sopraelevata su cinque gradini che ne disegna una specie di invito a metà tra lo spazio semi-pubblico e quello privato dei cortili a cul-de-sac caratteristici della Vucciria. La sagoma
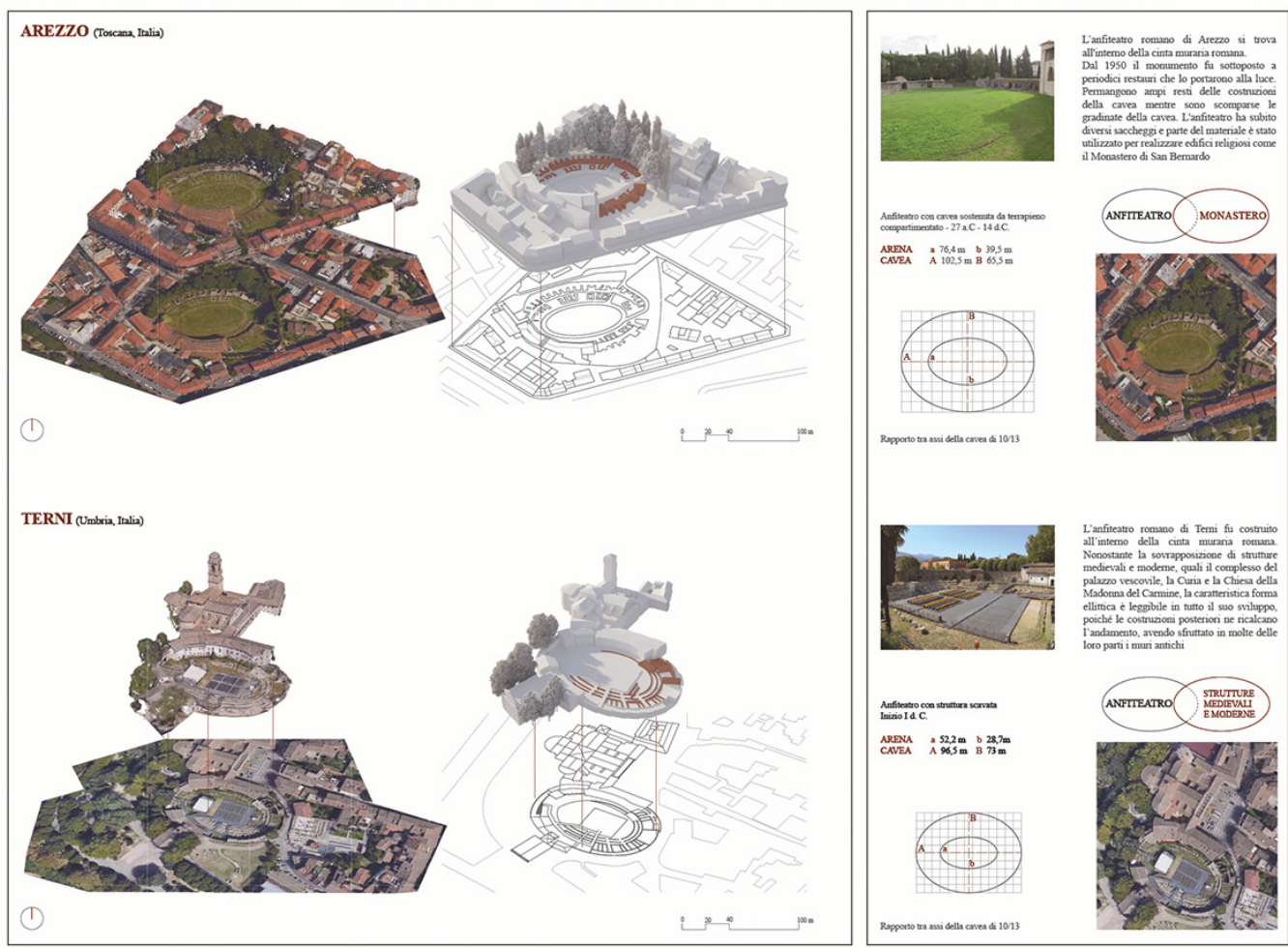
curva della porzione iniziale, raccordata con un arco di compasso e messa in relazione alle sue adiacenze - sia in entrambi gli isolati che lo definiscono che in quello che gli si prospetta di fronte - mostra in effetti già dalle prime operazioni di ridisegno delle corrispondenze di forma che sembra difficile addebitare a coincidenza, casualità, o modulazioni di curvatura dovute alle variazioni dell'orografia di sedime. Molti degli isolati della zona seguono infatti le tortuosità dovute ai movimenti della sponda settentrionale del Papireto su cui si erano originariamente insediati, mantenendone poi le tracce e la memoria nelle trasformazioni urbane delle epoche successive. Qui invece la curva appare rigida, identificabile come porzione di circonferenza da estendere e completare per pervenire a una prima ipotesi di ridefinizione dell'ingombro e delle dimensioni della geometria d'insieme. Però, insieme a elementi di continuità e di appoggio del disegno (muri curvilinei concentrici alla curva della strada negli isolati limitrofi; l'effettiva continuità di curvatura con la sagoma del muro perimetrale del medievale palazzo Ponza; setti radiali rinvenibili nel disegno dei piani terra delle abitazioni) ci sono un paio di elementi che, ponendosi parimenti come anomalie della forma architettonica e urbana da tenere in considerazione nell'indagine, ne interrompono bruscamente la continuità di forma in una ipotesi di riconfigurazione di un probabile anfiteatro. Si tratta di un frammento erratico di difficile attribuzione architettonica - con un passaggio ad arco e sostruzioni parimenti arcuate - presente all'interno del cortile Due Palme, e di due robusti pilastri, collegati ad altrettante arcature, presenti allinterno di due edifici separati (una bottega su via Monteleone e un ambiente al piano terra dell'Istituto del Banco di Credito). A un esame più attento, l'intera sagoma planimetrica dell'Istituto del Banco di Credito presenta numerose stranezze e irregolarità di disegno che, lette in un insieme esteso agli altri isolati e agli edifici ivi situati, permette una ricomposizione che ne giustificherebbe una logica e una motivazione. Che non è quella dell'anfiteatro ma, nel dipanarsi progressivo delle tessere del puzzle, rivela la possibile allocazione della sagoma di un edificio teatrale.

II Banco di Credito ha una storia che merita di essere riletta sotto una nuova luce: progettato da Pietro Scibilia negli anni ' 20 del $X X$ secolo a seguito del taglio della via Roma, nasce dall'assemblaggio delle macerie di due palazzi nobiliari preesistenti, la porzione residuale del
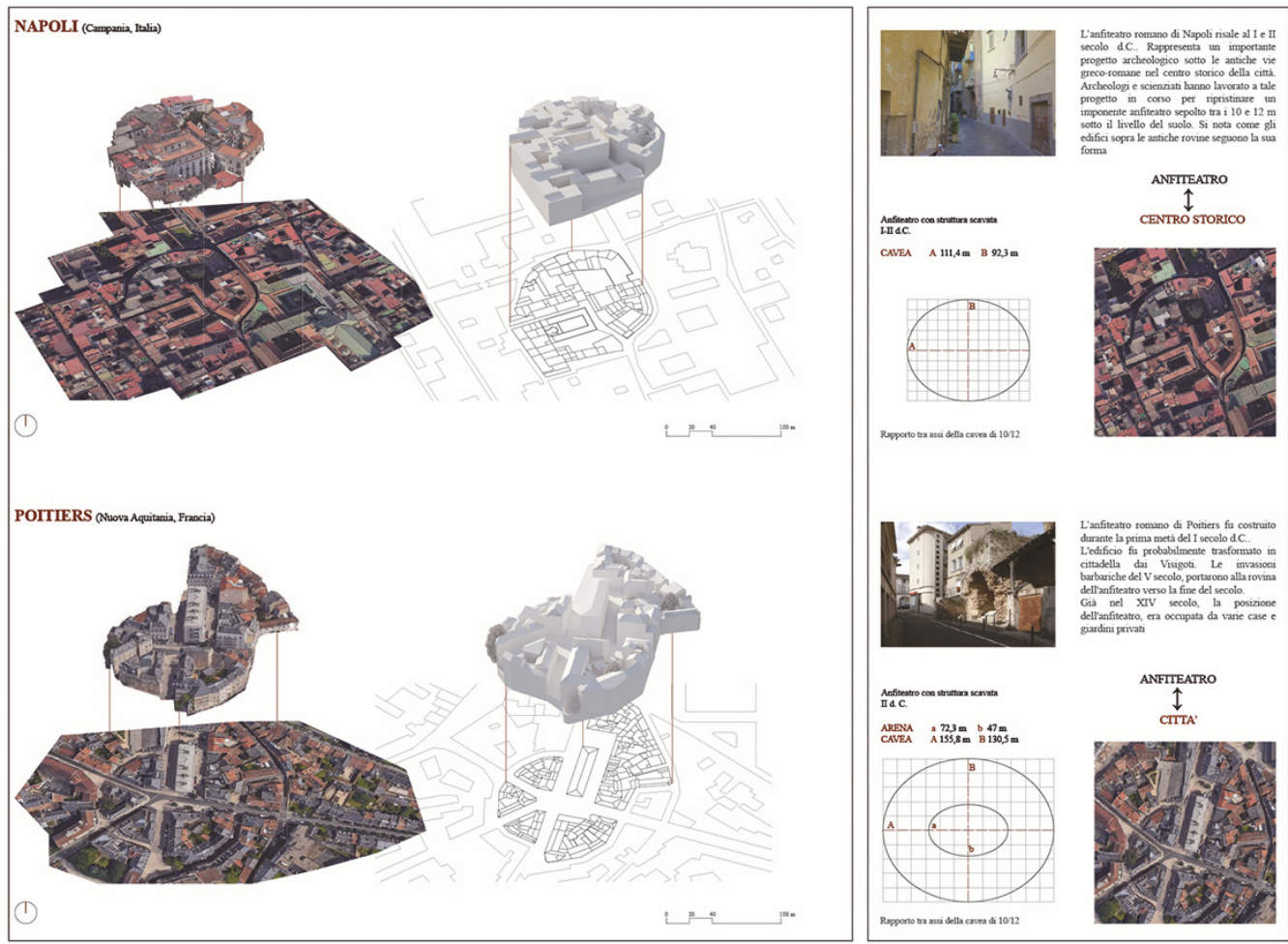
palazzo Pignatelli di Monteleone all'Olivella e il corpo centrale del palazzo Lanza di Mussomeli, che era già stato nel tempo accorpato e inglobato dal palazzo dei Pignatelli [Scibilia 20 I 3; Chirco 2008]. Entrambi i palazzi, di realizzazione cinquecentesca, si presentavano parimenti come assemblaggi di edifici preesistenti e più antichi: all'interno del palazzo Mussomeli il Villabianca menziona la presenza di una torre 'di antichità saracena', mentre sono note le vicende costruttive della galiila (una galleria adibita a pinacoteca) all'interno del maestoso giardino del palazzo Monteleone, e come questo elemento, staccato dall'architettura del palazzo, ne impreziosisse il lignaggio con elementi di gusto e derivazione archeologica come tozzi pilastri squadrati e arcature profonde in pietra da taglio [Piazza 20 I0; Vesco 20 I 0]. Se, come supponiamo e come ben si evince dalle foto scattate durante il cantiere del Palazzo delle Poste, il progetto di Scibilia partì dal presupposto di mantenere quanto più possibile delle strutture residue dei due palazzi e quindi rifoderarle in una nuova veste architettonica, ne consegue che sia la torre menzionata dal Villabianca che i resti delle strutture murarie della galleria siano ancora esistenti e soggiacenti al nuovo rivestimento novecentesco.

Andando ulteriormente a ritroso, la scomoda sagoma trapezia del palazzo Mussomeli può essere ricondotta all'aggancio tra cavea e proscenio del teatro, il vicolo san Basilio a uno

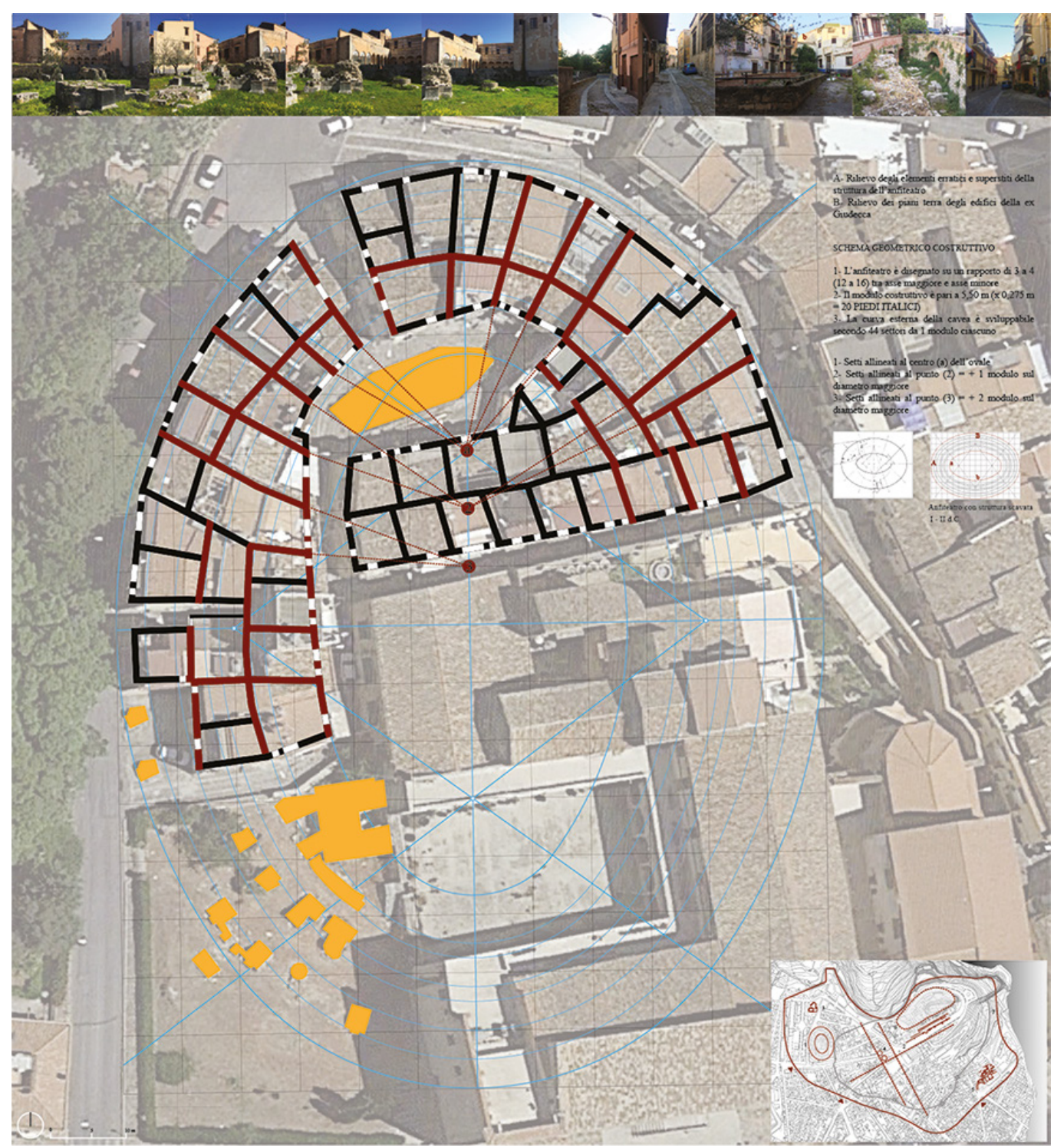


dei diazoma cui corrisponderebbe un adito (vomitorium) in linea con la via Monteleone, la torre - di cui rinveniamo la struttura quadrata nei ringrossi di muratura dei corpi scalari tuttora esistenti - con una delle torri scalarie del proscenio e la galleria del palazzo Pignatelli come una delle strutture porticate che, nell'architettura dei teatri, disegnavano il profilo retrostante e segnavano gli ingressi laterali. Anche l'intero complesso dello scomparso palazzo Monteleone, con i suoi disallineamenti altimetrici, le asimmetrie dei due cortili e l'indubbia focalizzazione aggregativa sul rettangolo tronco del grande giardino può essere ricondotto a una significativa preesistenza in grado di ricucirne i pezzi e risignificarne gli spazi: l'architettura del circo.

II giardino, e le due porzioni parallele di muro che lo recintavano, sarebbe quanto rimasto dell'arena e in altre strutture (come la bassa e larga cavallerizza e il raccordo obliquo tra i due cortili) potrebbero essere individuati elementi di chiara identificazione come il pulvinar e i carceres. L'insieme, così congetturalmente riconfigurato, ricorderebbe da vicino l'impianto planimetrico del complesso di Domiziano a Roma (l'attuale piazza Navona), consentendo al disegno di ricalcarne le stesse misure.

Consapevoli dell'assoluta mancanza d'indizi archeologici o documentari tali da poter volgere tali probabilità in certezze scientifiche, ci limitiamo a ritrovare e sottolineare come le coincidenze tra anomalie di forma degli isolati e improwise concentricità di alcuni setti murari interni agli edifici consentano un'agevole opera di ridisegno, che è però da intendersi, per ora, come operazione di totale fantasia ricostruttiva.

Fig. 6. Palermo, l'area tra piazza San Domenico e l'Olivella.

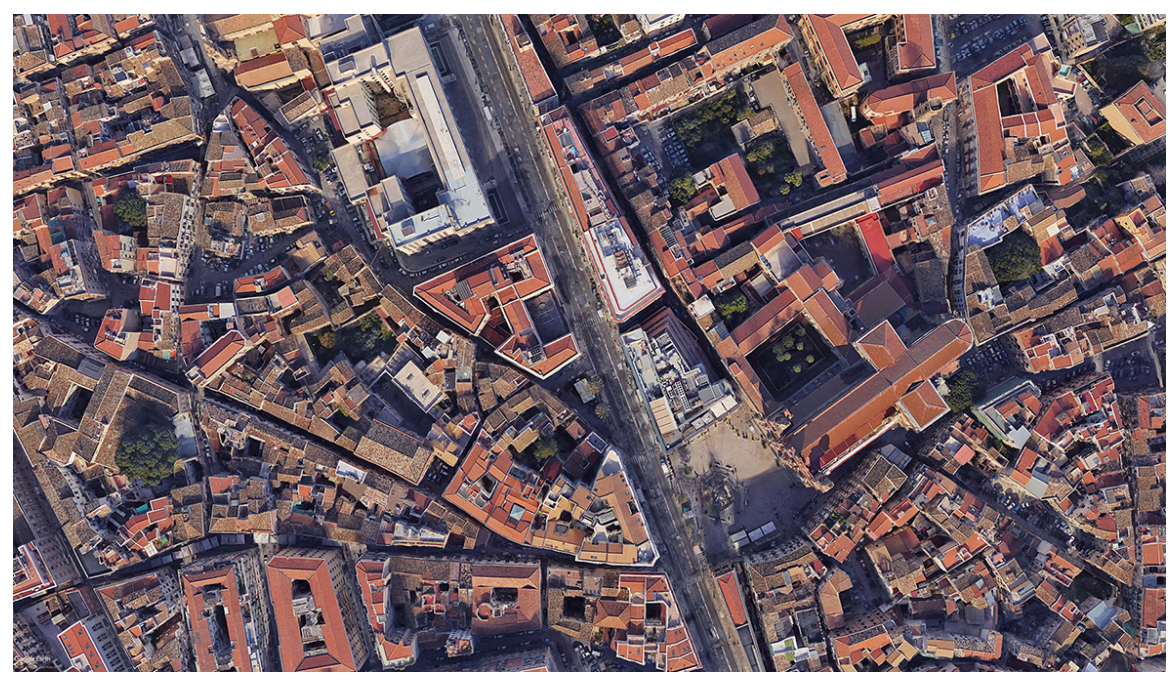

\section{Un 'quartiere degli spettacoli' all’Olivella?}

Allargando lo sguardo verso l'Olivella, non possono sfuggire caratteristiche del tutto simili - con curve interrotte che riprendono più oltre e setti murari concentrici e radiali - anche nelle zone limitrofe: l'isolato contiguo (tra via San Basilio, via Patania, piazzetta Lanza e via Monteleone) presenta un'insolita corrispondenza tra le diagonali date dalle giaciture del Collegio della Carità all'Olivella e della chiesa di San Gioacchino e la chiara leggibilità di una curva policentrica spezzata nella corte interna, tra l'ex Convento di San Basilio e le case medioevali dei Beccadelli-Bologna; i palazzi d'impianto più antico presentano, come già documentato per palazzo Mussomeli (e come anche nei vicini palazzo Ponza e palazzo del Pizzuto) corpi turriformi tozzi e squadrati avulsi dal contesto planimetrico dell'insieme, valorizzati a tratti dall'inserimento di bifore e merlature ma sospetti di esser preesistenti e più antichi della definizione dell'architettura trecentesca che li avrebbe inglobati: tali presenze 
Fig. 7.Vicolo San Basilio e le sue adiacenze. Rilievo dei piani terra.

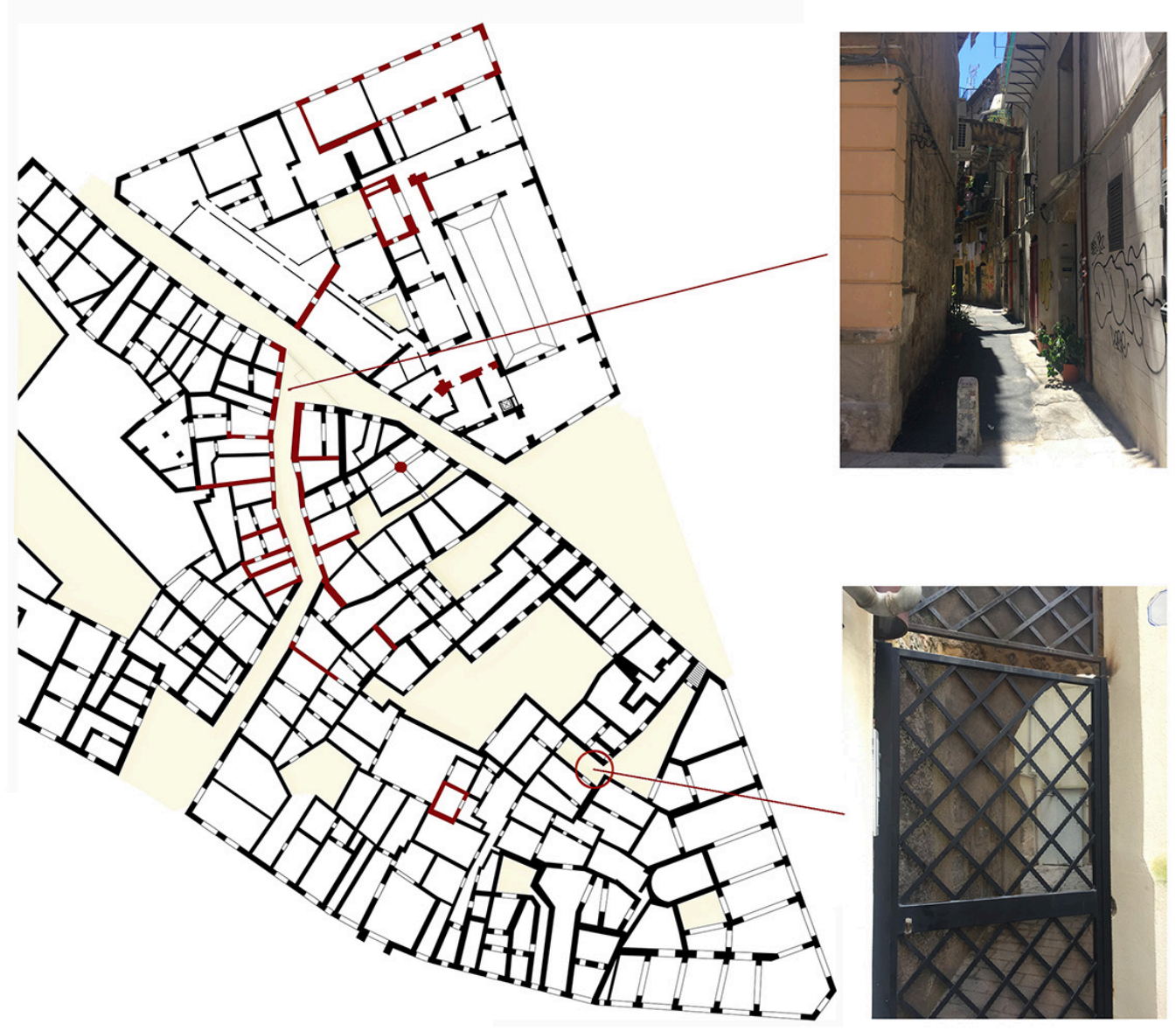

Fig. 8. Palazzo Lanza di del 1703 (Lazzara) e nel progetto di Scibilia
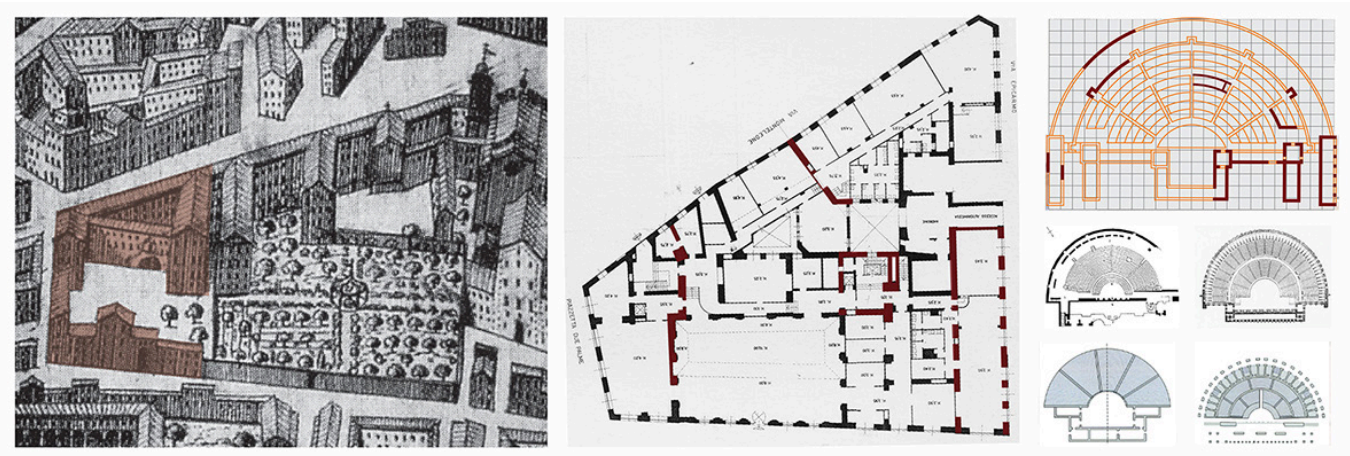
sono rintracciabili nelle corti interne di palazzo Beccadelli in via San Basilio e di palazzo Gregorio tra via San Basilio e via Patania. In continuità con l'operazione già avviata per l'isolato adiacente e applicando la stessa metodologia, è stato abbastanza facile e congruente alla morfologia del sito inserirvi la geometria d'impianto di un anfiteatro. Per la definizione dei rapporti geometrici e modulari ci si è appoggiati, per similitudine, alla ricostruzione ideale dell'anfiteatro di Termini Imerese: è possibile ottenere un ovale con rapporti improntati alla stessa concezione, sia per quel che riguarda la curva interna dell'arena che la curva esterna della cavea, con dimensioni qui leggermente maggiori [Belvedere 1982; Belvedere 1993; Buscemi 2007; Trevisan 1998; Golvin 1988].

Le tre architetture, così riconfigurate, dichiarerebbero una concezione progettuale unitaria, serrata e concentrata in una sorta di Quartiere degli Spettacoli (il rimando diretto è Pompei, ma anche Catania), immediatamente extraurbano e allineato sulla percorrenza principale della via Bandiera che viene facile immaginare come l'asse già delineato e tracciato di una delle principali strade della viabilità esterna d'epoca antica: la via Valeria.

Anche gli interni di palazzo Lanza Mazzarino (con il suo notevole giardino pensile e il sottostante ambiente ipostilo), palazzo Ramondetta-Sammartino e palazzo Pignocco (con la straordinaria e sorprendente sequenza di archi a raggiera disposti nel basso che attualmente

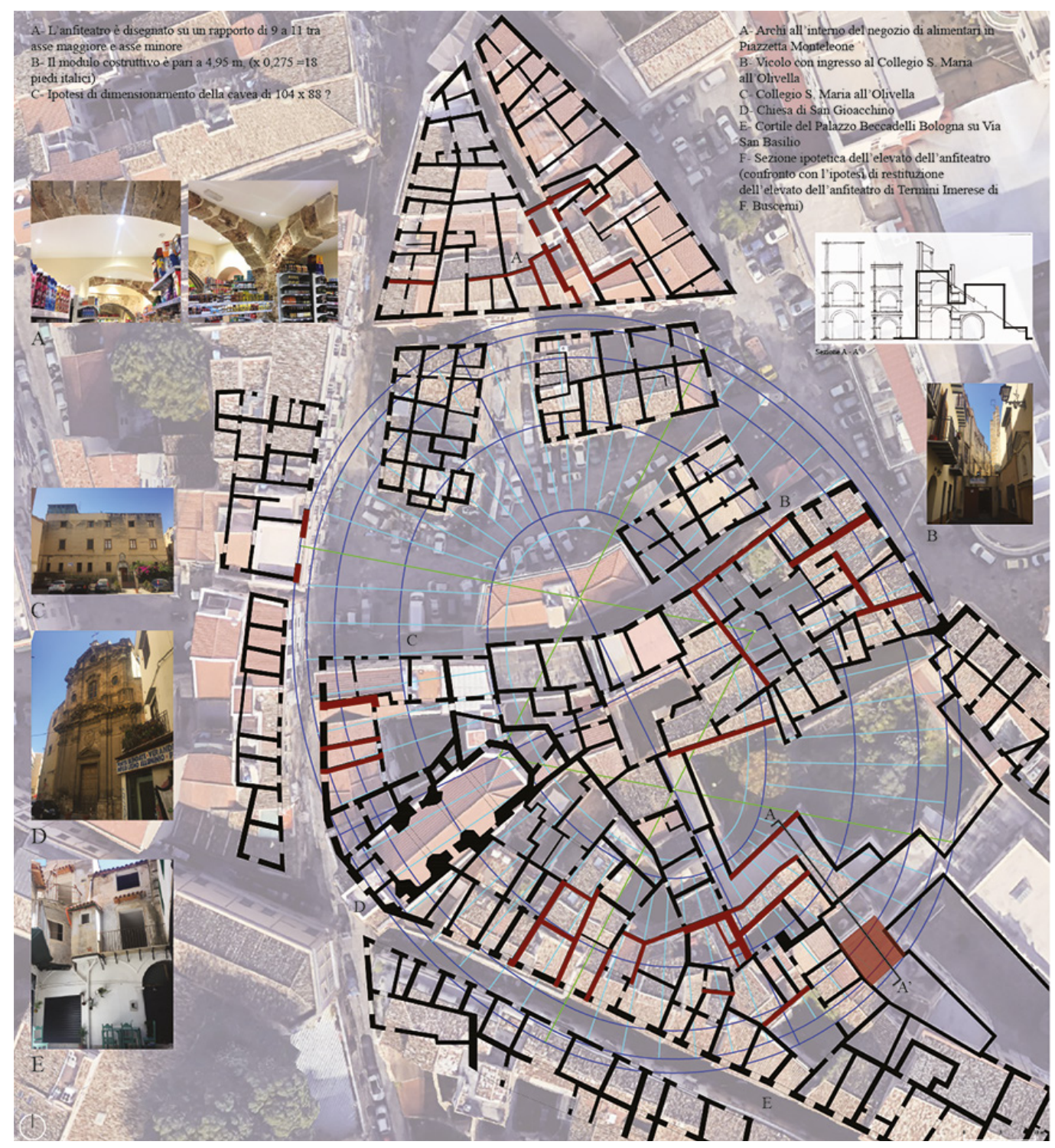


Fig 10. Palazzo Pignatelli di Monteleone,

ricostruzione della piant (Piazza) e foto d'epoca.

Fig. I I. Pianta d'insieme (è stata inserita la porzione demolita de palazzo Pignatelli di Monteleone)
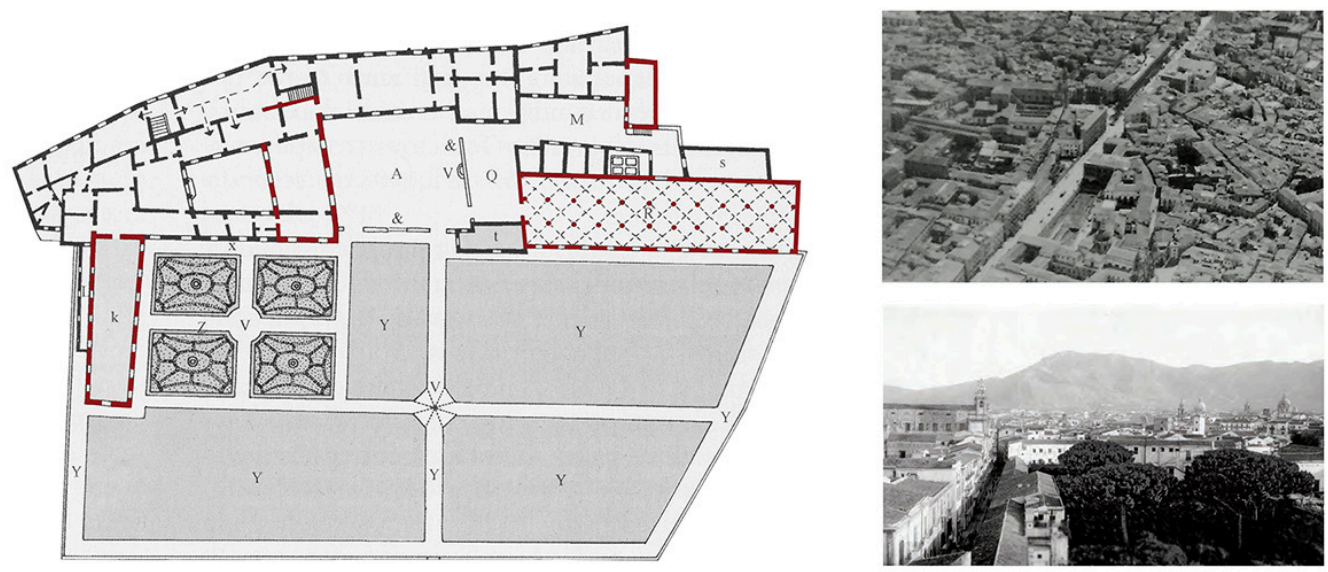

è adibito a minimarket) potrebbero riservare sorprese e ulteriori aggiunte a questa traccia di lavoro. Così come sarebbero da catalogare e ridefinire tutti quegli elementi di reimpiego (colonne, lapidi, fontane, capitelli) che si trovano sparsi e incastonati qua e là in tutte le architetture già menzionate. Potrebbe essere uno spunto per una nuova campagna di rilievi orientata e direzionata in tal senso.

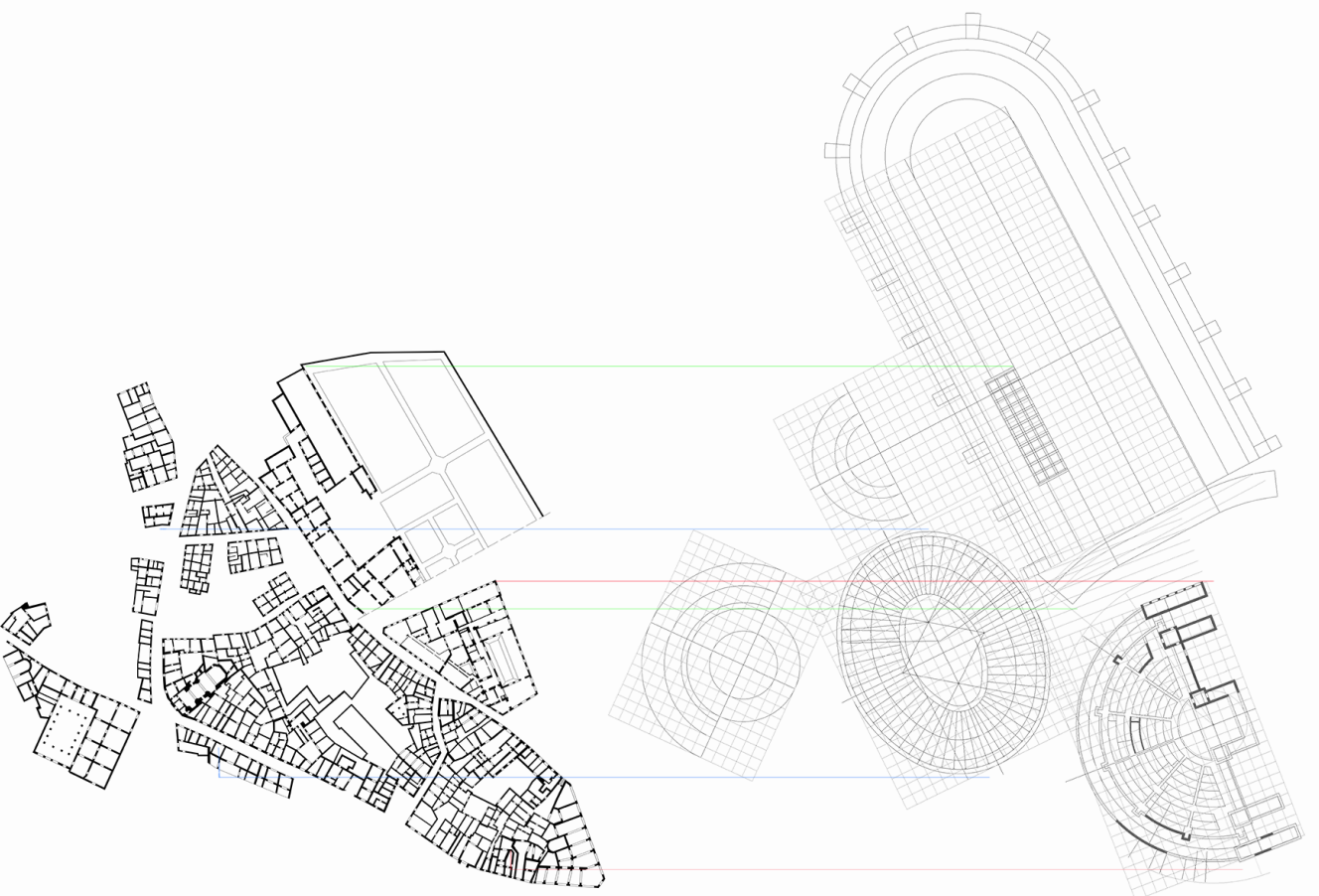

Riferimenti bibliografici

Adriani Elena (2005). Storia del teatro antico. Roma: Carocci.

Belvedere Oscar (1982). L'Anfiteatro di Termini Imerese riscoperto. In AAV. Aparchai. Nuove ricerche e studi sulla Magna Grecia e la Sicilia Antica in onore di P.E. Arias. Pisa: Giardini, pp. 23-35.

Belvedere Oscar, Burgio Aurelio, Macaluso Rosalia et. al. (1993). Termini Imerese, ricerche di topografia e di archeologia urbana. Palermo: Istituto di Archeologia dell'Università di Palermo.

Belvedere Oscar, Bergemann Johannes (a cura di). (20।8). La Sicilia Romana: Città e Territorio tra monumentalizzazione ed economia, crisi e sviluppo. Palermo: Palermo University Press. 
Buscemi Francesca (2007). Architettura e romanizzazione nella Sicilia di età imperiale: gli edifici per spettacoli. Siracusa: Società Siracusana di Storia Patria.

Chirco Adriana, Di Liberto Mario (2008). Via Roma. La strada nuova del '900. Palermo: Flaccovio.

Chirco Adriana (20 I I). Del palazzo che c'era, non ci fu e non c'è più. Ovvero che fine ha fatto palazzo Monteleone? In PER (Salvare Palermo), n.29, 201 I, pp. 10 - I3.

Girgenti Gian Marco, Pollara Giorgio (2018). L'anfiteatro romano di Termini Imerese. Ricostruzioni virtuali e vicende storico/ architettoniche del sito urbano. In Agribusiness Paesaggio \& Ambiente, n. 2, Dicembre 20 I 8, vol. XXI, pp. 97- I I I.

Golvin Jean-Claude (1988). L'Amphithéatre roman: essai sur la théorisation de sa forme et de ses fonctions. Paris: De Boccard.

Golvin Jean-Claude (2008). L'Amphithéatre de Pompéi, monument de transition. In Nikephoros, n. 20, 2008, pp. $199-207$.

Golvin Jean-Claude (20 I I). L'Amphithéatre et ses images. Quelque règles fondamentales du langage visuel. In Actes du Vème, Congrès International d'Archéologie et d'Histoire de l'Art, INHA 20 I I. < http://www.inha.fr/colloques:document.php?id=2366. en $2011>$.

Golvin Jean-Claude (2012). L'Amphitéatre romain et les jeux du cirque dans le monde antique. Paris: Archeologie Nouvelle.

Humphrey John H. (1986). Roman Circuses: Arenas for Chariot Racing. Berkeley \& Los Angeles: University of California Press.

lacobone Damiano (2008). Gli anfiteatri in Italia tra Tardo Antico e Medioevo. Roma: Gangemi Editore.

Lo Cascio Pippo (2006). Le torri di Palermo. Palermo: Edizioni del Mirto.

Malfitana Daniele, Mazzaglia Antonino (2018). Archeologia globale a Catania. Nuove prospettive dallintegrazione di ricerca archeologica e tecnologie ICT. Nuovi dati sull'anfiteatro romano. In Belvedere Oscar, Bergemann Johannes (a cura di). La Sicilia Romana: Città e Territorio tra monumentalizzazione ed economia, crisi e sviluppo. Palermo: Palermo University Press. pp. $327-352$.

Piazza Stefano (20 I0). Note su alcuni giardini settecenteschi dei palazzi nobiliari palermitani. In Sessa Ettore, Mauro Eliana (a cura di). Il valore della classicità nella cultura del giardino e del paesaggio. Palermo: Grafill, pp 403-4I7.

Santagati Luigi (2006). Viabilità e topografia della Sicilia antica. Caltanissetta: Paruzzo.

Scibilia Federica, Scibilia Nunzio (2013). Pietro Scibilia ingegnere architetto (I 889-197|). Roma:Aracne.

Spatafora Francesca (2003). Nuovi dati sulla topografia di Palermo. In Quarte giornate internazionali di studi sull'Area Elima, Erice I-4 dicembre 2000, Pisa: Scuola Normale Superiore. pp. I I75- I I88.

Storchi Paolo (2013). Per l'identificazione dell'anfiteatro di Palermo romana e considerazioni su altri edifici per spettacolo. In Atlante tematico di Topografia Antica, n.23, 2013, pp. 6I-7I.

Storchi Paolo (20 I3). Palermo romana: trovato l'anfiteatro? In Archeologia viva, set-ott 20 I3, pp. 6I-7I.

Storchi Paolo (20|4). Topographical reconstruction of ancient Palermo: a note on its buildings for public spectacles and their relation with the Roman-period civic planning. In Proceedings of Landscape Archaeology Conference (LAC), Roma, I7-20 sett. 2014, pp. I-9. <http://lac20 | 4proceedings.nl/article/view/80>.

Tamburello Ida (1998). Palermo punico-romana. La storia dei rinvenimenti archeologici. Palermo: Luxograph.

Trevisan Camillo (1998). Sullo schema geometrico costruttivo degli anfiteatri romani: gli esempi del Colosseo e dell'Arena di Verona. In Disegnare idee immagini, n. 18/19, 1998, pp. 117-132.

Vesco Maurizio (2010). Un cantiere barocco a Palermo: il palazzo di Diego Aragona e Tagliavia, duca di Terranova. In Lexicon, n. I0/1 I, 2010, pp. 98-102.

\section{Autori}

Gian Marco Girgenti, Università degli Studi di Palermo, gianmarco.girgenti@unipa.it Claudia Tarantino, Università degli Studi di Palermo, claudia.tarantino92@gmail.com

Per citare questo capitolo: Girgenti Gian Marco, Tarantino Claudia (2020). Connessioni e stratificazioni della forma urbana. Le tracce degli anfiteatri romani e le loro risignificazioni/Connections and stratifications of the urban shape. The traces of the Roman anphitheaters in their metamorphoses. In Arena A., Arena M., Brandolino R.G., Colistra D., Ginex G., Mediati D., Nucifora S., Raffa P. (a cura di). Connettere. Un disegno per annodare e tessere. Atti del $42^{\circ}$ Convegno Internazionale dei Docenti delle Discipline della Rappresentazione/Connecting. Drawing for weaving relationships. Proceedings of the 42th International Conference of Representation Disciplines Teachers. Milano: FrancoAngeli, pp. I I 83-1204. 


\section{Connections and Stratifications of the Urban Shape. The Traces of the Roman Anphitheaters in Their Metamorphoses}

Gian Marco Girgenti

Claudia Tarantino

\section{Abstract}

Starting from the survey of the remains of Termini Imerese Roman Amphitheatre and considering both its virtual reconfiguration and the architectural events that have seen the succession of different urban stratifications and re-significations, we have concentrated our interest on the cases that have determined the changes in shape and the archaeological sedimentations of some amphitheatres in Italy and Europe. From these preliminary operations the investigation work was carried out on Palermo, wanting to verify - through the survey and the redrawing of the urban fabric - the compatibility of the most recent hypotheses of location of the buildings for spectacles in the Panormus of the Roman age.

Keywords

urban analysis, 3D reconstructions, roman theatres and amphitheatres.
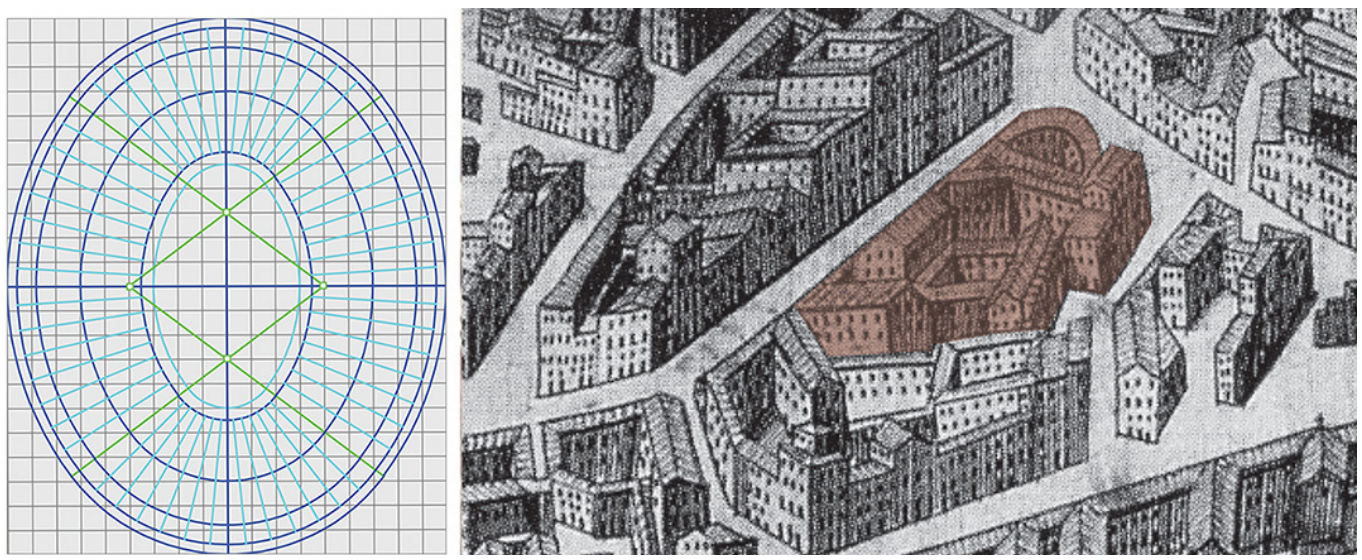


\section{Introduction}

With regard to the reflections on the forma urbis of the city of Palermo in its pre-Renaissance version, we can notice an oversizing of the contribution offered during the period of Islamic domination compared to that of Roman domination. The surviving architectural traces are scarce for both periods, yet the myth of the Saracen Balarm, either for the undoubted 'exotic' fascination, or for the push given by the Arab studies -from Amari onwards- is stronger and more persistent than that of the Panormus of republican and imperial age. There was enough agreement in the attribution to the Aghlabid dynasty of the first extra-moenia urban expansion, continued with the Fatimites and the Kalbites. Giving almost a substantial inertia that continued throughout the Byzantine domination, the question remains as to the role played by Roman architecture and urban planning in the space of about seven centuries, after the Punic Zyz took them into 254 BC. The news regarding the image of the urbs of the time are few, even if there is no shortage of documentary sources and studies on the matter. The general idea that is handed down lies in the definition of 'Punic-Roman city' as if the Palermitan Romanitas had settled in the previous Phoenician plant without substantial alterations or transformations of the same. Among the most recent archaeological prospections, the discovery and highlight of the insula in Piazza Sett'Angeli, with the remains of a domus paved with mosaics with geometric motifs equal in importance and workmanship to the villa in Piazza Vittoria, is of considerable interest.

The impression that there is still a lot to find is strong, especially with regard to the building initiatives that have most characterized Roman cities wherever they have settled, from public works such as streets and aqueducts to monumental spaces such as forums, theatres and amphitheatres. The most updated compendium of studies on Roman Sicily, published in 20 I 8 by Oscar Belvedere and Johannes Bergemann, offers a complete and exhaustive overview of many Sicilian cities: however, due to absence, the interest dedicated to Panormus, a prominent city, stands out and of undoubted importance, as evidenced by its insertion both in the Itinerarium Antonini and in the Tabula Peutingeriana.
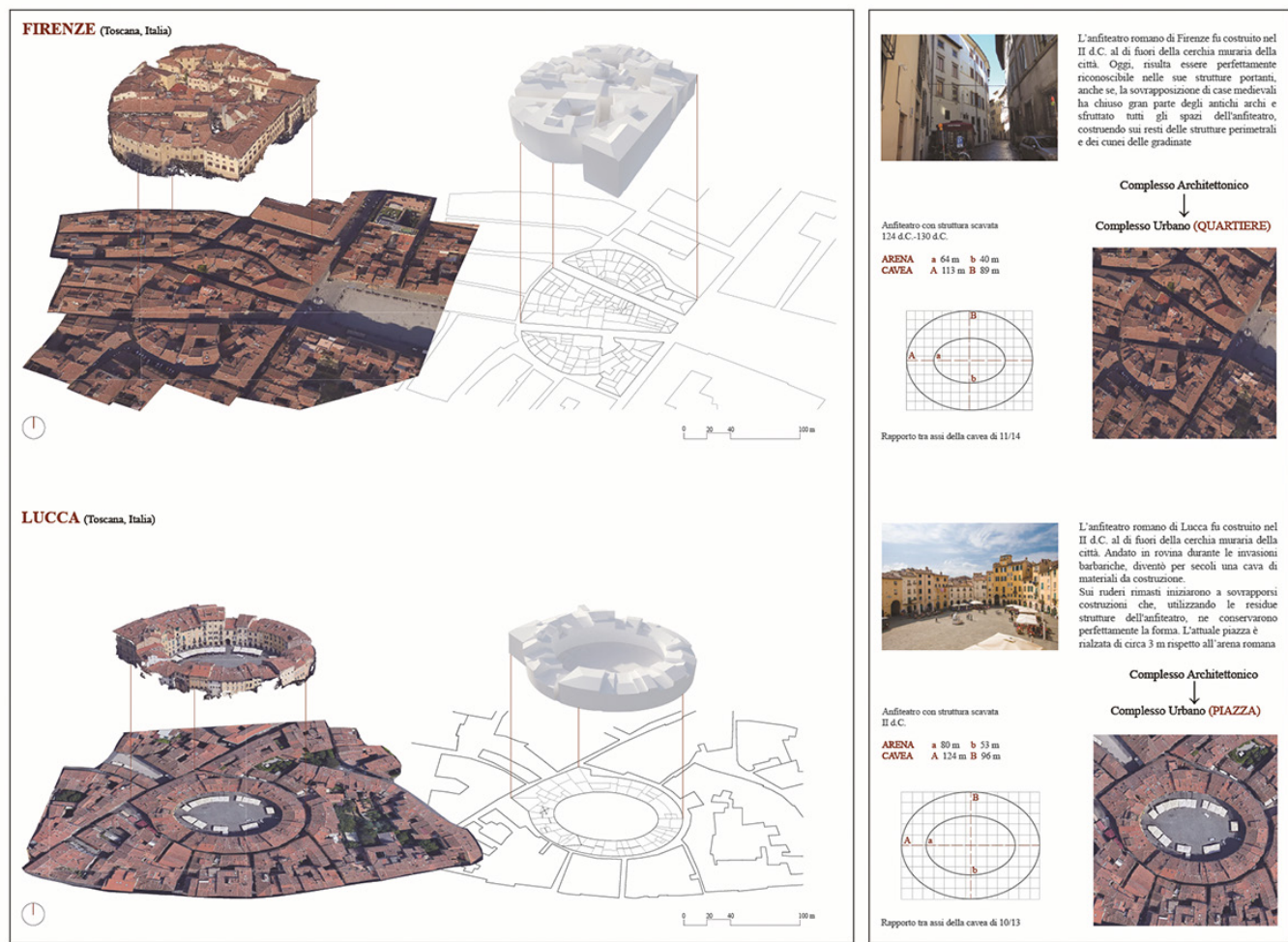
Particularly interesting, for the areas of the study that we propose here, is the essay by Daniele Malfitana and Antonino Mazzaglia on the Catania Amphitheatre, in the framework of a project of 'Multidisciplinary Global Archeology' called 'OpenCiTy', open to skills ranging beyond the specificity of archaeological studies (and their necessary concentration and fragmentation) and which involves looks and operations that could offer, with different and integrated methods and methodologies, a 'knowledge plan' open to the public and in constant updating and development. The knowledge and related discoveries about Catania, which have successively affected the discovery of the Theatre, the Odeon and the Amphitheatre, are in this case a fairly pertinent example of knowing in progress and in constant development.

Paolo Storchi seems to be moving in the same direction. For the identification and identification of buildings never found or located but whose existence was almost certain, he proposes a working method that anticipates the possibility of the excavation campaign with a crossed look between the analysis of the morphology of the city and the careful study of remote sensed satellite images, in search of traces or anomalies of the urban fabric as a possible 'spy' of older presences. Due to the peculiarity of their conformation and the rigid modular application of the geometries of the plant, the young scholar has so far concentrated the objective of his research on buildings for entertainment, especially amphitheatres, offering localization hypotheses that, in one case out of three (Reggio Emilia) turned out to be exact. Among its location hypotheses there is also Palermo, and it is from its suggestions that we have tried to develop a possible reasoning on the shape and evolution of the Sicilian capital in Roman times in relation to the information deduced from the analysis of the ancient topography.

Fig. 2. Variations of meaning: Resignifications (from building for spectacles to garden)
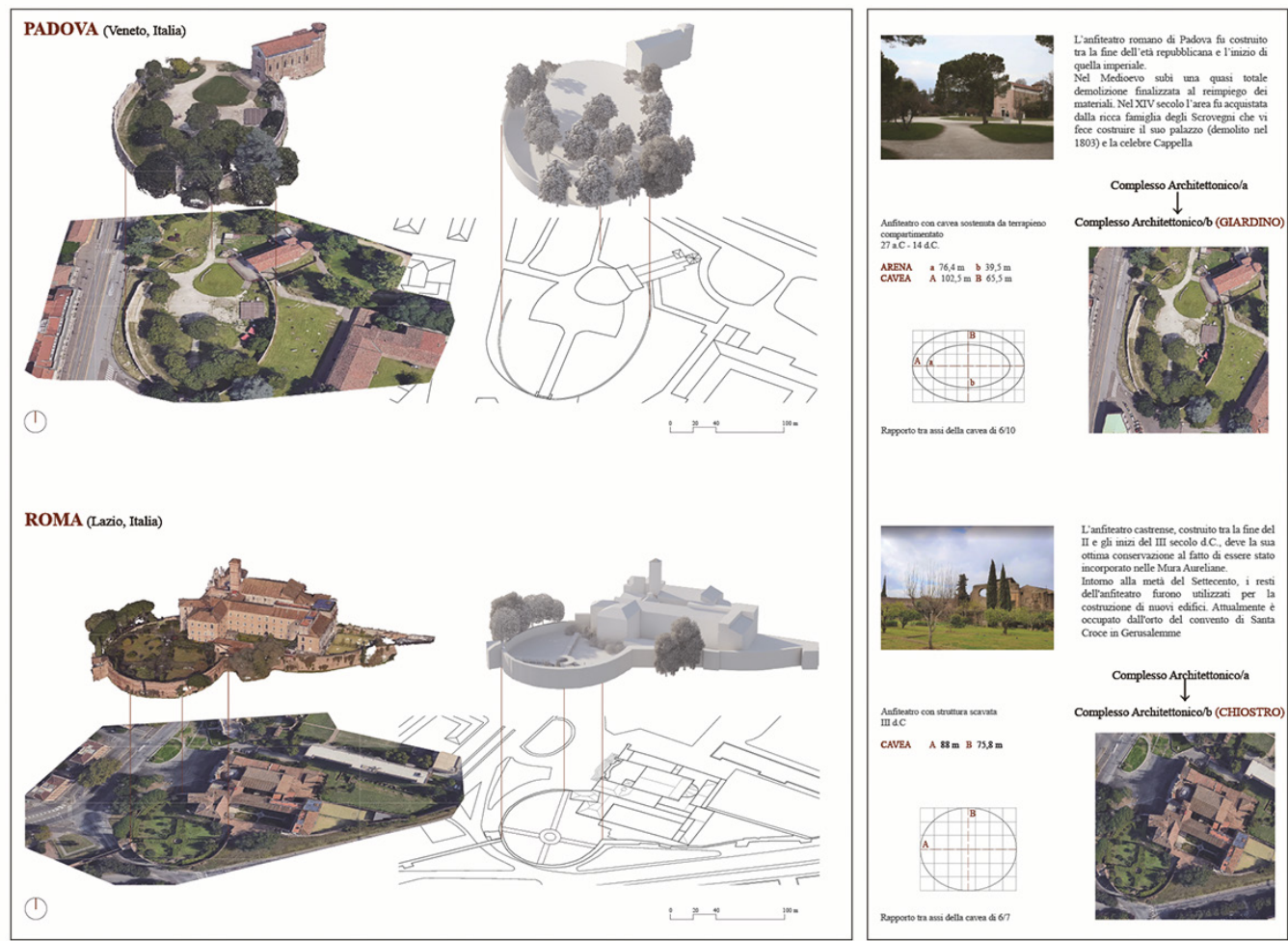


\section{The Hypotheses of localization of the ampfhitheater in Palermo}

We can be sure of the presence of an amphitheatre in Palermo, built in stone and in line with similar Sicilian realizations (Catania,Termini Imerese). Perhaps the most interesting aspect of Storchi's hypothesis concerns its possible location, in the area between Piazza San Domenico and the Olivella district. The area, contextualized according to the ancient topography, was outside the perimeter of the walls and was not very urbanized: adjacent to the Port and the Castellammare (the Castrum Inferius) it could be the area of choice more appropriate for the installation of a building for gladiatorial and venation shows, which would have required accessory spaces and connected buildings (such as ludi, gyms and barracks) difficult to achieve within a city already defined in its development and in its perimeter by the scheme hippodameus of Paleapolis and Neapolis. The same area could have, in its immediate vicinity, a more imposing and monumental work such as a circus for equestrian races (expressly mentioned by John H. Humphrey following the Descriptio Totius Mundi of the Justinian age). Storchi advances more than legitimate doubts between the comparison of the Sala Viridis on the Piano del Palazzo with a possible Roman Theater, thus launching the challenge to broaden the horizon for research on the possible location of this too.

The contribution that we can offer, in synergy with Storchi's brilliant intuitions, can concern the survey and the consequent three-dimensional modelling, on an urban and therefore architectural and detailed scale, and the transfer of data in visual communication platforms based on the Catania experience of 'Open CiTy'.

The starting point of our investigations, after the recognition of the cadastral plans and the on-site inspection, was the San Basilio alley between via San Basilio and via Monteleone: it is a narrow and winding road that can be divided into two sections, one rectilinear the other curvilinear, and which mediates the different altimetries between the two streets with an elevated platform on five steps that draws a kind of invitation halfway between the semi-public and private spaces of the cul-de-sac courtyards characteristic of Vucciria. The curved shape of the initial portion, connected with a compass arch and placed in relation

Fig. 3. Urban

stratifications: Parasitism (the new engulfs the ancient).
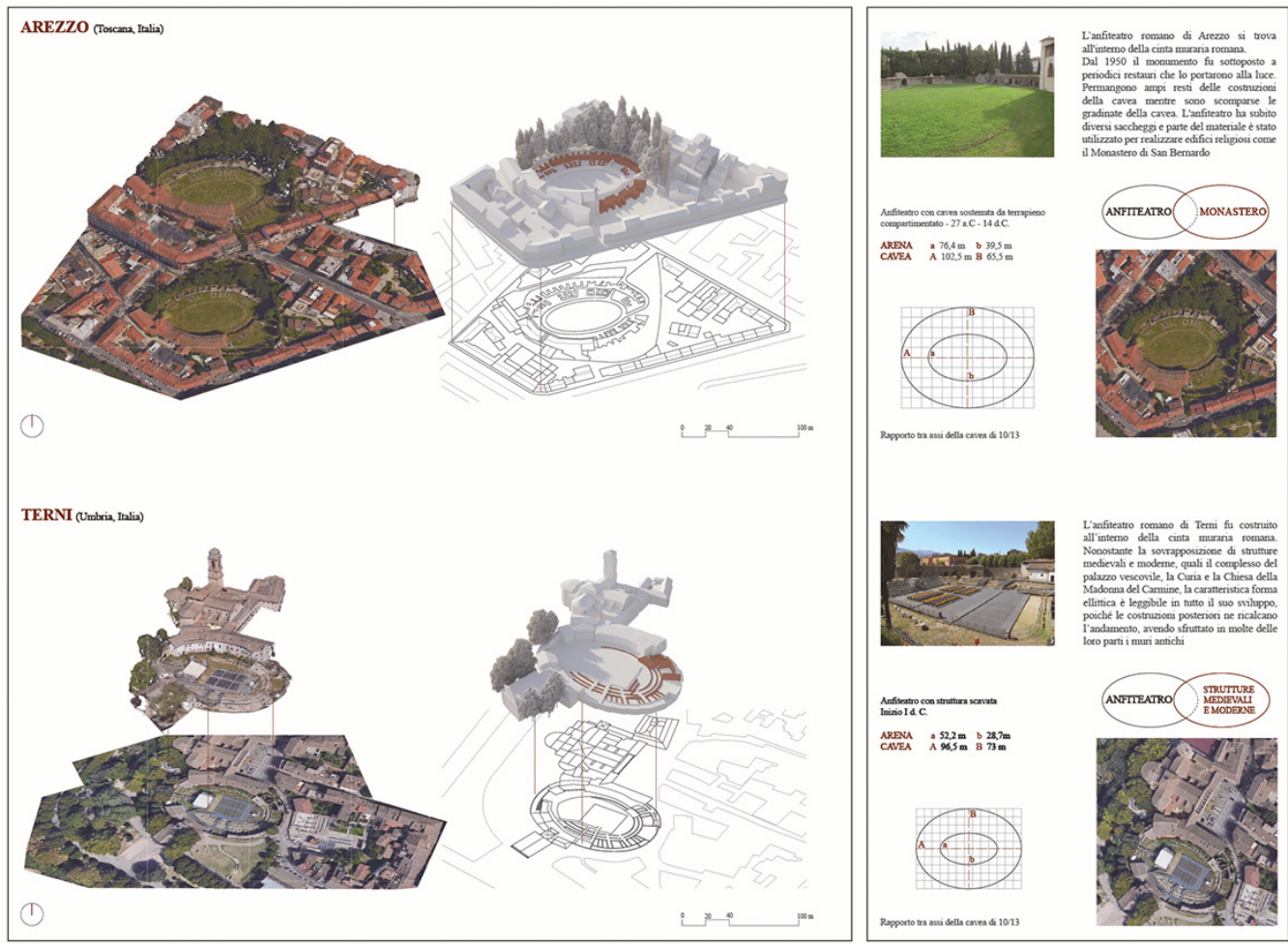
to its adjacencies -both in the blocks that define it and in what is facing it- actually shows from the first operations of redesigning the correspondences shape that seems difficult to attribute to coincidence, randomness, or curvature modulations due to variations in the orography of the grounds. In fact, many of the blocks in the area follow the tortuosity due to the movements of the northern bank of the Papireto on which they had originally settled, then keeping their traces and memory in the urban transformations of the following eras. Here, however, the curve appears rigid, identifiable as a portion of circumference to be extended and completed in order to arrive at a first hypothesis of redefining the overall dimensions and dimensions of the overall geometry. Instead, together with elements of continuity and support of the design (curvilinear walls concentric to the curve of the road in the neighbouring blocks; the effective continuity of curvature with the shape of the perimeter wall of the medieval Palazzo Ponza; radial walls found in the ground floors of the housing) there are a couple of elements which, placing themselves as anomalies of the architectural and urban form to be taken into consideration in the investigation, abruptly interrupt the continuity of form in a hypothesis of reconfiguration of a probable amphitheatre. We are talking about an erratic fragment of difficult architectural attribution -with an arched passage and equally arched substructures- present inside the Due Palme courtyard, and two robust pillars, connected to as many arches, present within two separate buildings ( a shop on via Monteleone and a hall on the ground floor of the Istituto del Banco di Credito). On closer inspection, the entire planimetric outline of the Istituto del Banco di Credito presents numerous oddities and irregularities of design which, read in a set extended to the other blocks and buildings located there, allows a recomposition that would justify a logical and a motivation. Which is not that of the amphitheatre but, in the progressive unravelling of the pieces of the puzzle, reveals the possible allocation of the shape of a theatre building. The Banco di Credito has a history that deserves to be reread in a new light: designed by Pietro Scibilia in the 1920s following the cutting of Via Roma, it was born from the assembly of the rubble of two pre-existing noble palaces, the portion residue of the Palazzo Pignatelli di Monteleone in Olivella and the central body of the Palazzo Lanza of Mussomeli, which had
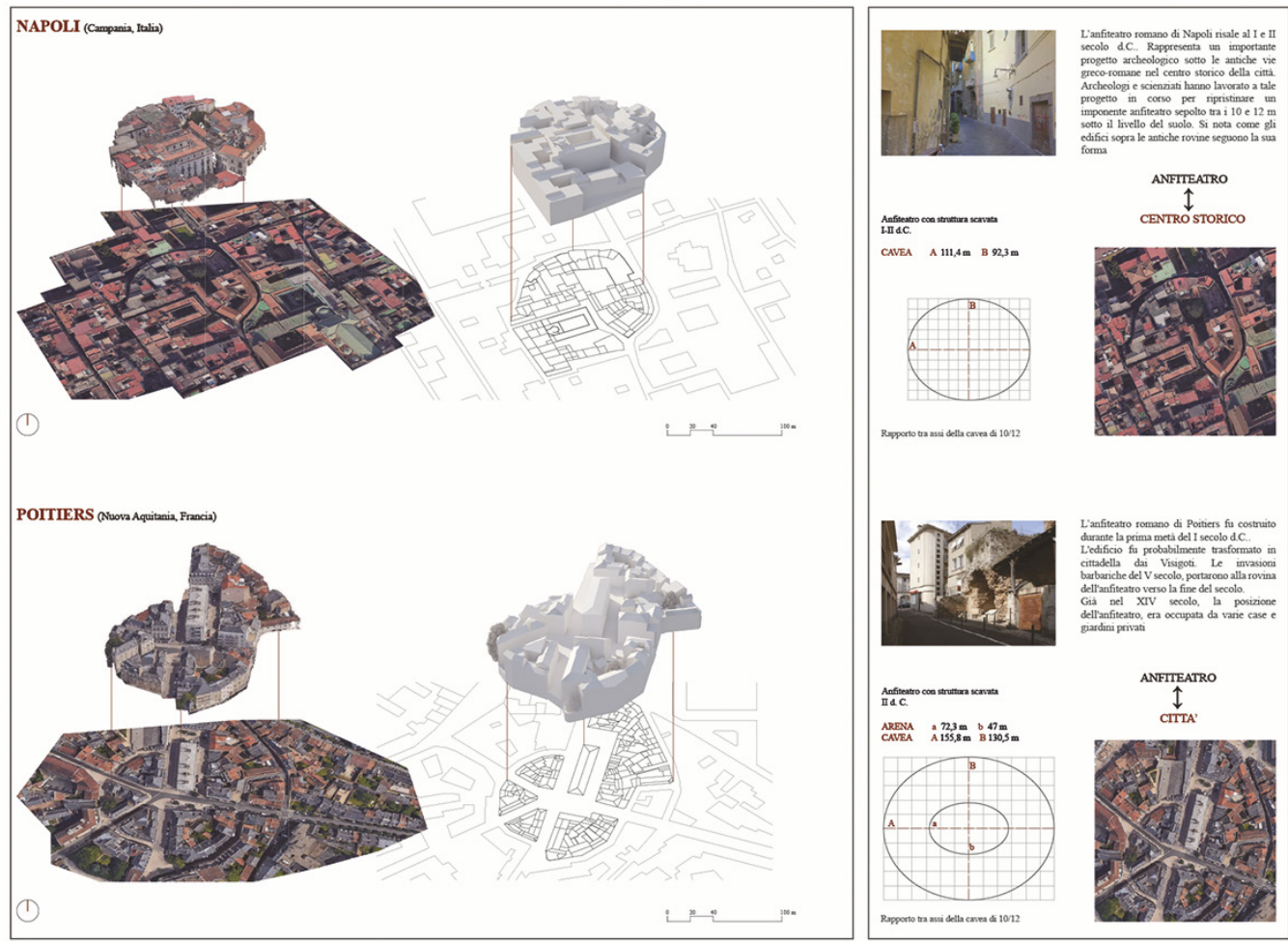
already been merged and incorporated into the Palazzo dei Pignatelli over time. Both palaces, built in the sixteenth century, also presented themselves as assemblies of pre-existing and older buildings: inside the Palazzo Mussomeli the Villabianca mentions the presence of a tower 'of Saracen antiquity', while the construction events of the 'galiila' (a gallery used as paintings exhibition) are known, inside the majestic garden of the Monteleone palace, and how this element, detached from the architecture of the palace, embellished its lineage with elements of taste and archaeological derivation such as squat squared pillars and deep stone arches from cut. If, as we suppose and as is well evident from the photos taken during the construction of the Palazzo delle Poste, Scibilia's project started from the assumption of keeping as much as possible of the residual structures of the two buildings and then re-decorating them in a new architectural guise, it follows that both the tower mentioned by Villabianca and the remains of the gallery's wall structures are still in existence and underlying the new twentieth-century cladding. Going further backwards, the uncomfortable trapezoidal shape of the Mussomeli palace can be traced back to the connection between the auditorium and the proscenium of the theater, the alley of San Basilio to one of the diazomata which would correspond to an adyton in line with via Monteleone, the tower-of

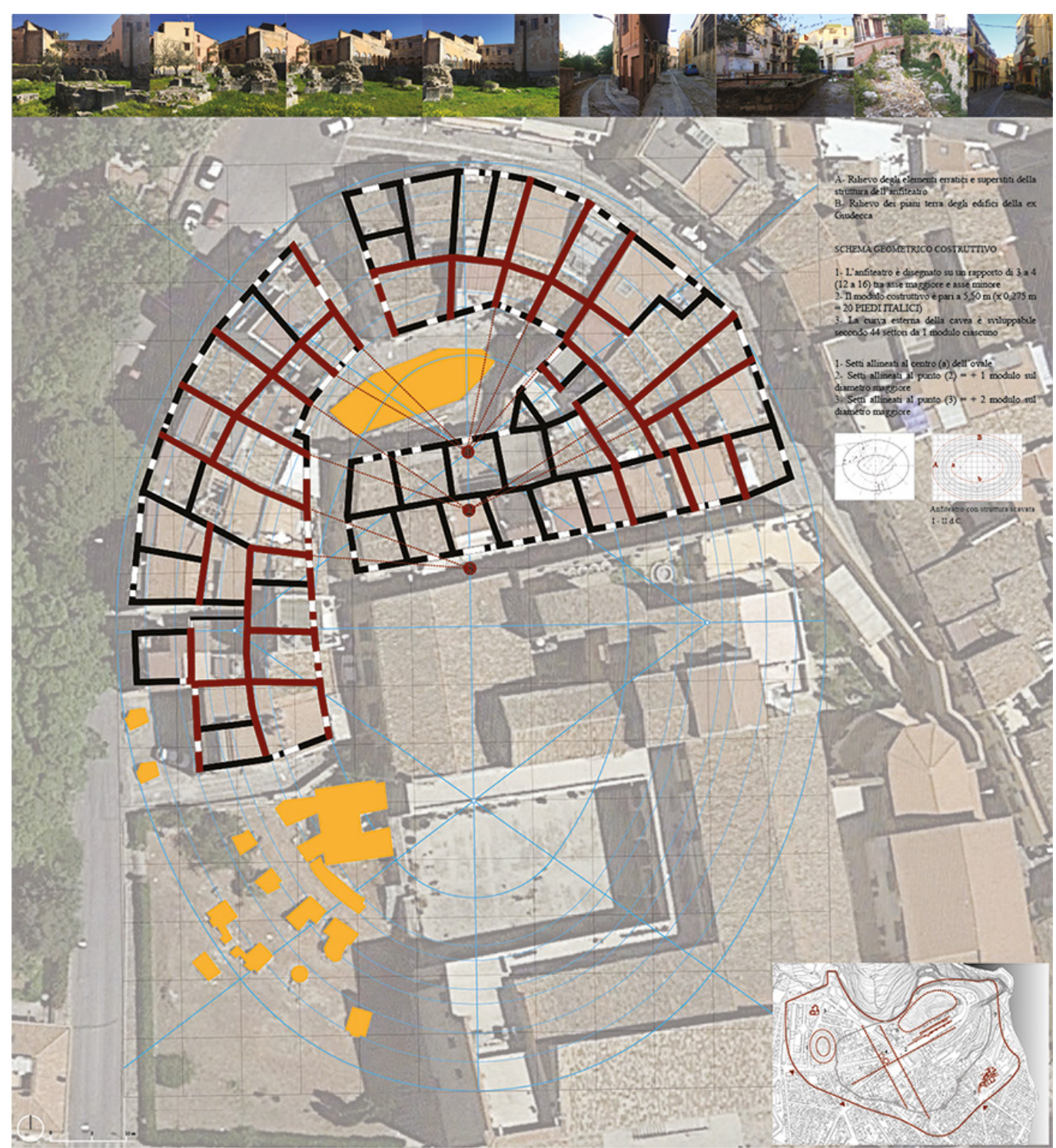


which we find the square structure in the masonry wholes of the still existing scalar bodieswith one of the scalar towers of the proscenium and the gallery of the Palazzo Pignatelli as one of the porticoes structures that, in the architecture of the theatres, drew the back profile and marked the side entrances.

Even the entire complex of the disappeared Monteleone palace, with its altimetric misalignments, the asymmetries of the two courtyards and the undoubted aggregative focus on the truncated rectangle of the large garden can be traced back to a significant pre-existence capable of stitching up the pieces and re-signifying the spaces: the architecture of the circus. The garden, and the two parallel portions of the wall that enclosed it, would be what remained of the arena and in other structures (such as the low and wide stable and the oblique connection between the two courtyards), it is possible to identify elements such as the pulvinar and the carceres. The whole complex, thus conjecturally reconfigured, would closely resemble the planimetric layout of the Domitian complex in Rome (the current Piazza Navona), allowing the design to follow the same measures.

Aware of the absolute lack of archaeological or documentary clues that can turn these probabilities into scientific certainties, we limit ourselves to finding and underlining how the coincidences between shape anomalies of the blocks and sudden concentricity of some walls inside the buildings allow an easy work redesign, which is to be understood, for now, as an operation of total reconstructive fantasy.

Fig. 6. Palermo, the area between Piazza San Domenico and the Olivella district.

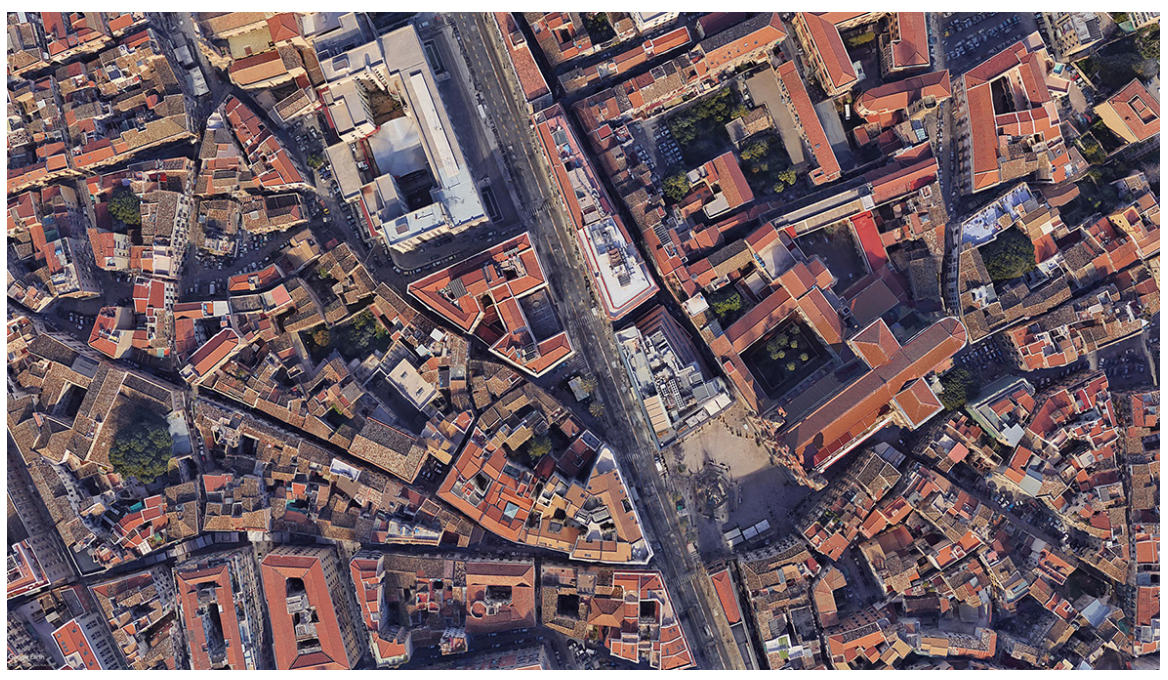

\section{A 'spettacle district' at the Olivella?}

Broadening our gaze towards Olivella, completely similar characteristics cannot be missed -with interrupted curves that resume further and concentric and radial walls- even in the neighbouring areas: the adjoining block (between via San Basilio, via Patania, piazzetta Lanza and via Monteleone) presents an unusual correspondence between the diagonals given by the laying of the Collegio della Carità all'Olivella and the church of San Gioacchino and the clear legibility of a polycentric curve broken in the internal courtyard, between the former Convent of San Basilio and the medieval houses of the Beccadelli-Bologna; the oldest buildings have, as already documented for Palazzo Mussomeli (and also in the nearby Palazzo Ponza and Palazzo del Pizzuto), squat and square turriform blocks detached from the planimetric context of the whole, enhanced at times by the insertion of mullioned windows and battlements but we suspect that they were pre-existing and more ancient than the 

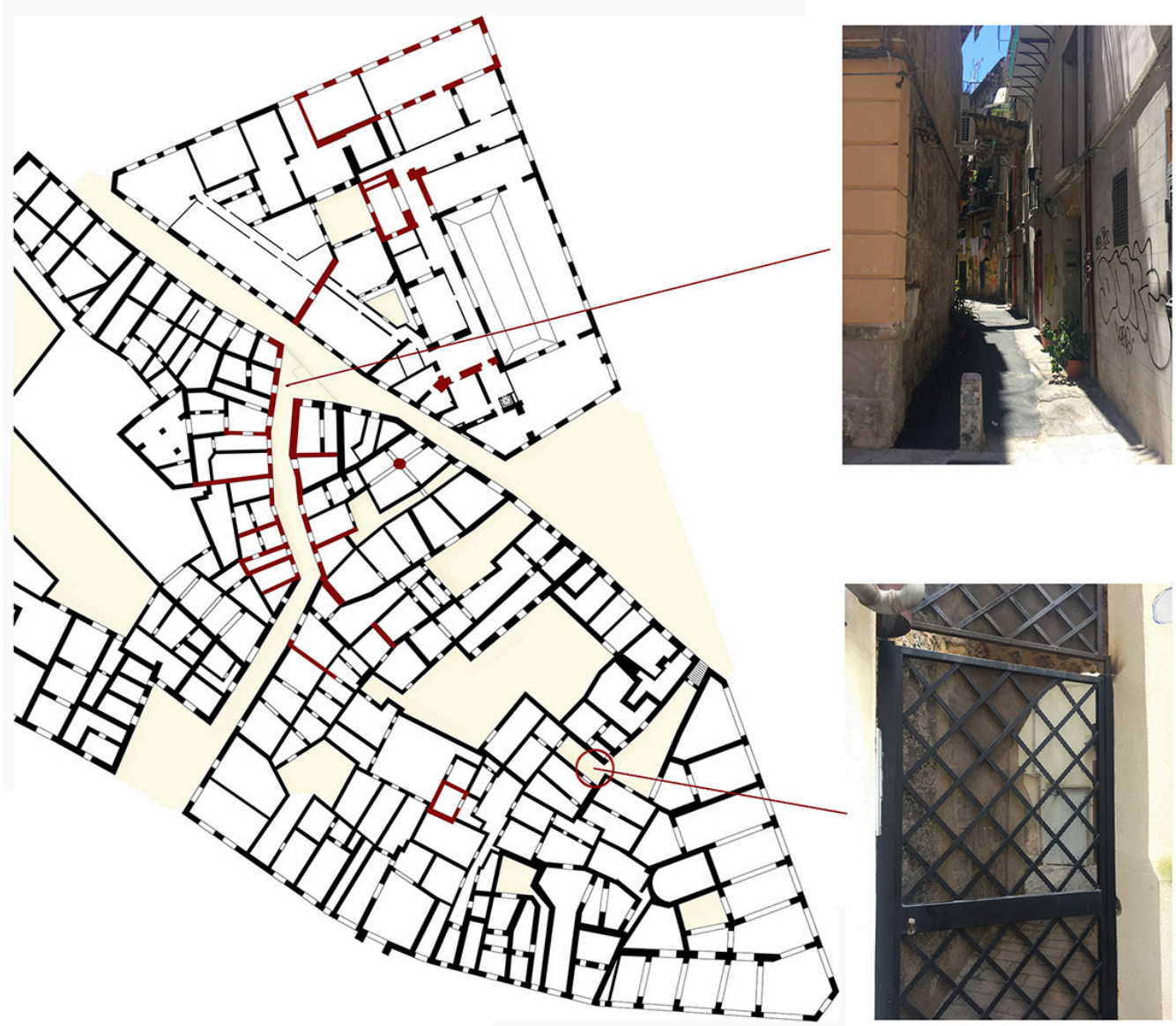

Fig. 8. Palazzo Lanza di Mussomeli in a view of the project of Scibilia
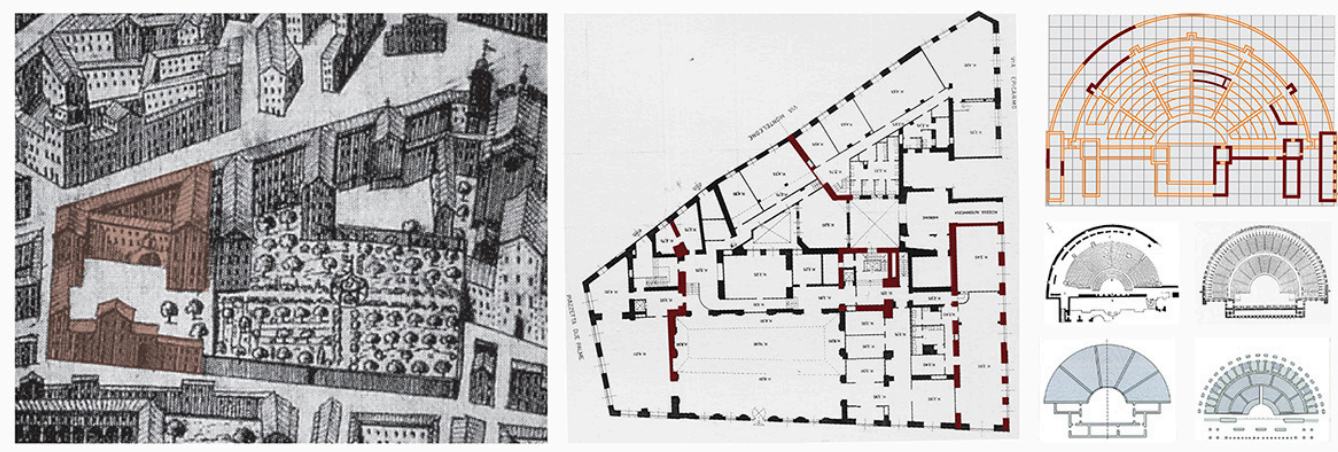
definition of the fourteenth-century architecture that would have incorporated them: these presences can be found in the internal courtyards of Palazzo Beccadelli in via San Basilio and Palazzo Gregorio between via San Basilio and via Patania. In continuity with the operation already started for the adjacent block and applying the same methodology, it was quite easy and congruent to the morphology of the site to insert the geometry of the plant of an amphitheatre. For the definition of the geometric and modular relationships, we have relied, for similitude, on the ideal reconstruction of the Termini Imerese amphitheatre: it is possible to obtain an oval with relationships based on the same conception, both as regards the internal curve of the arena and the external curve of the cavea, here with slightly larger dimensions. The three architectures, thus reconfigured, would declare a unitary design concept, tight and concentrated in a sort of 'Entertainment District' (the direct reference is Pompeii, but also Catania), immediately extra-urban and aligned on the main route of the Via Bandiera which is easy imagine how the axis already outlined and traced of one of the main roads of the ancient vintage road system: via Valeria.

Even the interiors of Palazzo Lanza Mazzarino (with its remarkable hanging garden and the underlying hypostyle room), Palazzo Ramondetta-Sammartino and Palazzo Pignocco (with the extraordinary and surprising sequence of radial arches arranged in the lower part which

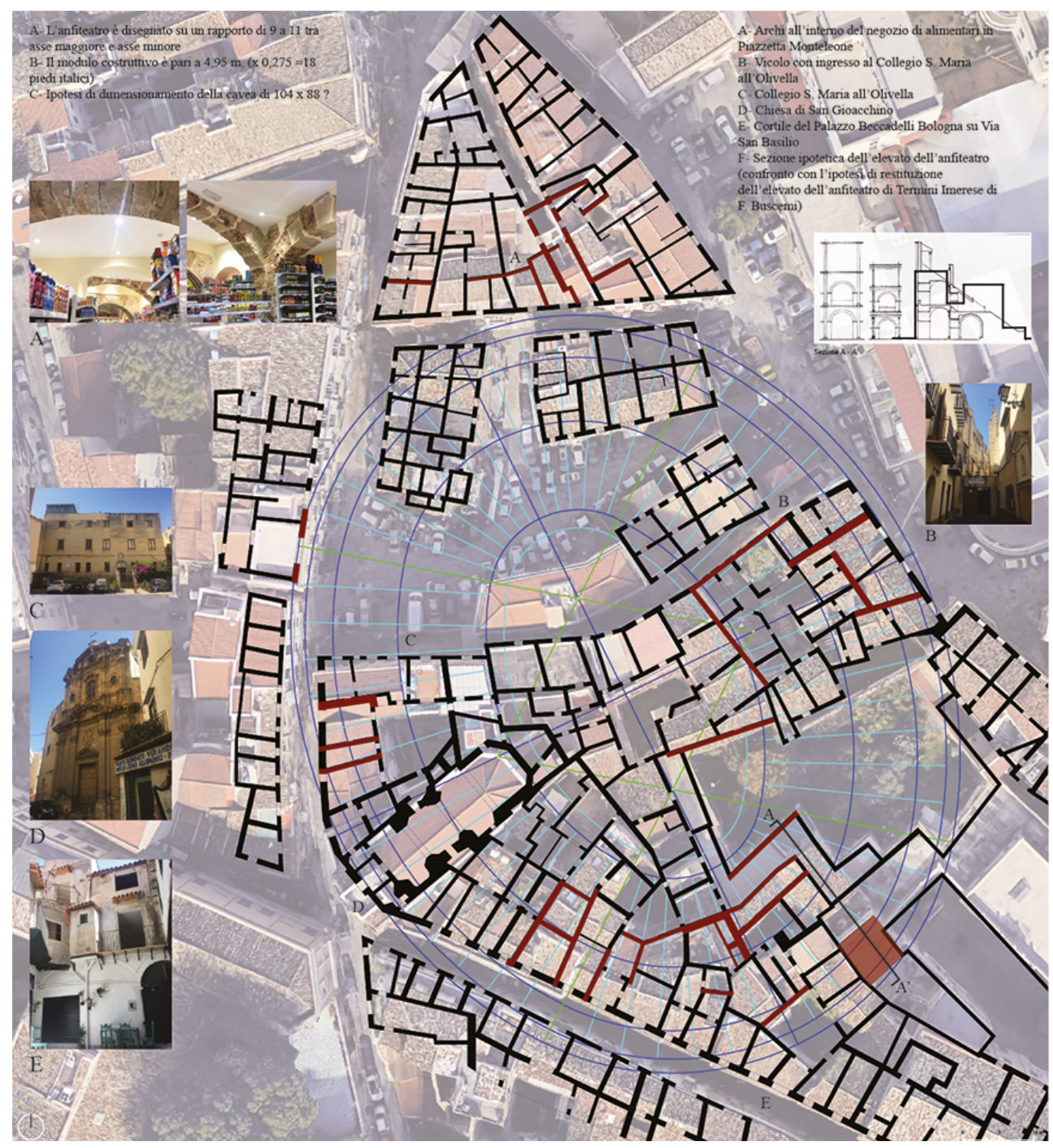


Fig. 10. Palazzo Pignatelli di Monteleone, reconstruction of the plan (Piazza) and vintage photos.

Fig. I I. Overall plan (with the insertion of the demolished portion of palazzo Monteleone).
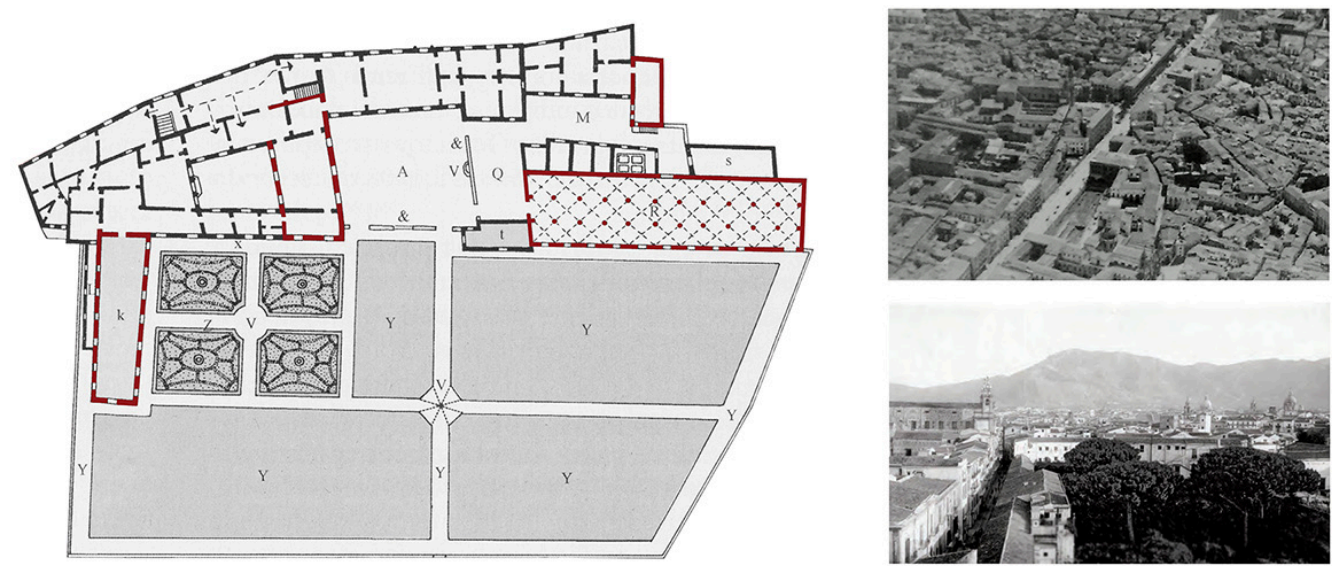

is currently used as a minimarket) could reserve surprises and further additions to this work track. Just as all those elements of reuse (columns, gravestones, fountains, capitals) that are scattered and set here and there in all the architectures already mentioned would have to be catalogued and redefined. It could be a starting point for a new survey campaign oriented and directed in this direction.

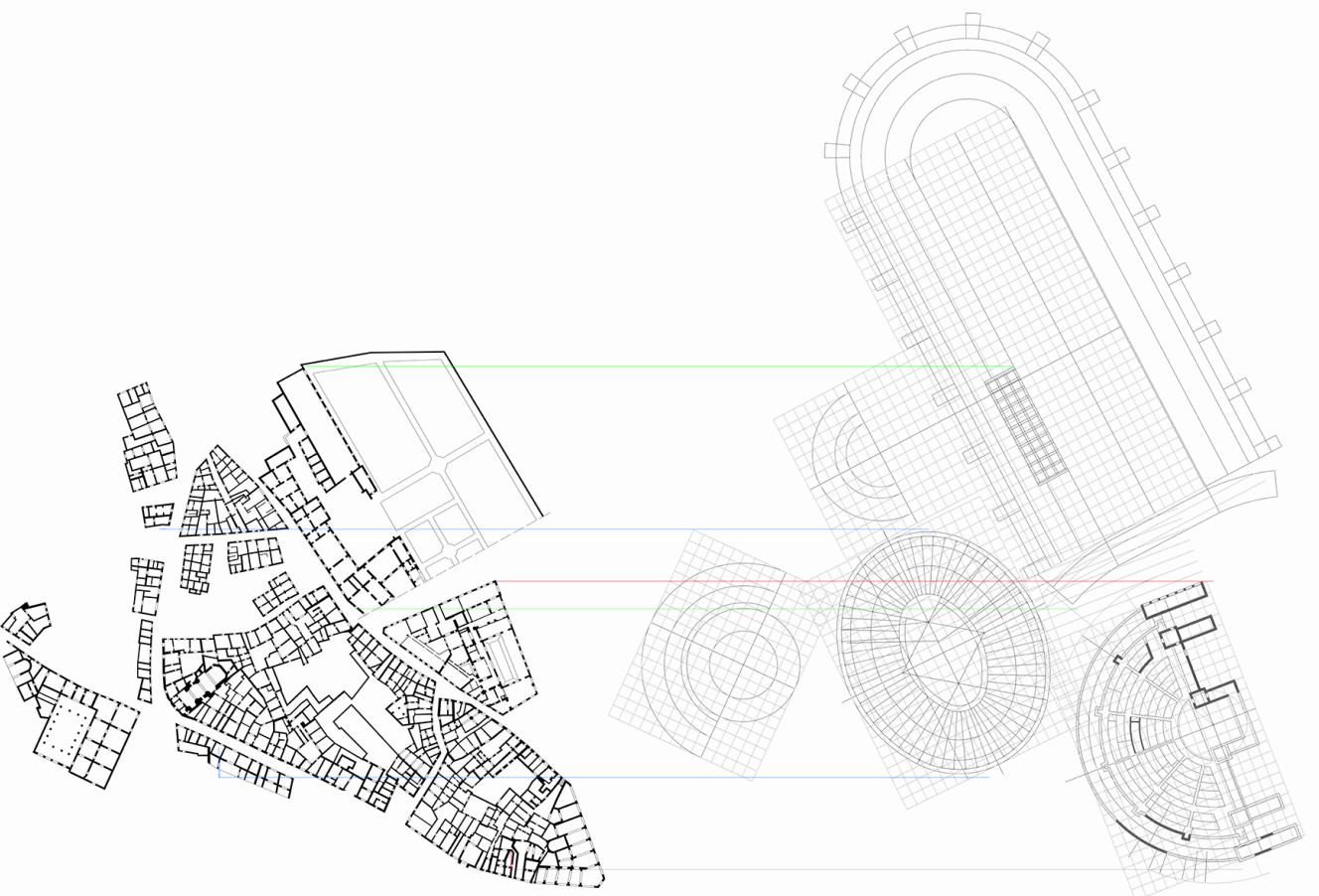

References

Adriani Elena (2005). Storia del teatro antico. Roma: Carocci

Belvedere Oscar (1982). L'Anfiteatro di Termini Imerese riscoperto. In AAV. Aparchai. Nuove ricerche e studi sulla Magna Grecia e la Sicilia Antica in onore di P.E. Arias. Pisa: Giardini. pp. 23-35.

Belvedere Oscar, Burgio Aurelio, Macaluso Rosalia et. al. (1993). Termini Imerese, ricerche di topografia e di archeologia urbana. Palermo: Istituto di Archeologia dell'Università di Palermo.

Belvedere Oscar, Bergemann Johannes (a cura di). (20।8). La Sicilia Romana: Città e Territorio tra monumentalizzazione ed economia, crisi e sviluppo. Palermo: Palermo University Press. 
Buscemi Francesca (2007). Architettura e romanizzazione nella Sicilia di età imperiale: gli edifici per spettacoli. Siracusa: Società Siracusana di Storia Patria.

Chirco Adriana, Di Liberto Mario (2008). Via Roma. La strada nuova del '900. Palermo: Flaccovio.

Chirco Adriana (20 I I). Del palazzo che c'era, non ci fu e non c'è più. Ovvero che fine ha fatto palazzo Monteleone? In PER (Salvare Palermo), n.29, 201 I, pp. 10 - I3.

Girgenti Gian Marco, Pollara Giorgio (20।8). L'anfiteatro romano di Termini Imerese. Ricostruzioni virtuali e vicende storico/ architettoniche del sito urbano. In Agribusiness Paesaggio \& Ambiente, n. 2, Dicembre 20 I 8, vol. XXI, pp. 97- I I I.

Golvin Jean-Claude (1988). L'Amphithéatre roman: essai sur la théorisation de sa forme et de ses fonctions. Paris: De Boccard.

Golvin Jean-Claude (2008). L'Amphithéatre de Pompéi, monument de transition. In Nikephoros, n. 20, 2008, pp. $199-207$

Golvin Jean-Claude (20 I I). L'Amphithéatre et ses images. Quelque règles fondamentales du langage visuel. In Actes du Vème, Congrès International d'Archéologie et d'Histoire de l'Art, INHA 20 I I. < http://www.inha.fr/colloques:document.php?id=2366. en $2011>$.

Golvin Jean-Claude (2012). L'Amphitéatre romain et les jeux du cirque dans le monde antique. Paris: Archeologie Nouvelle.

Humphrey John H. (1986). Roman Circuses: Arenas for Chariot Racing. Berkeley \& Los Angeles: University of California Press.

lacobone Damiano (2008). Gli anfiteatri in Italia tra Tardo Antico e Medioevo. Roma: Gangemi Editore.

Lo Cascio Pippo (2006). Le torri di Palermo. Palermo: Edizioni del Mirto.

Malfitana Daniele, Mazzaglia Antonino (20l8). Archeologia globale a Catania. Nuove prospettive dallintegrazione di ricerca archeologica e tecnologie ICT. Nuovi dati sull'anfiteatro romano. In Belvedere Oscar, Bergemann Johannes (a cura di). La Sicilia Romana: Città e Territorio tra monumentalizzazione ed economia, crisi e sviluppo. Palermo: Palermo University Press. pp. $327-352$.

Piazza Stefano (20 I0). Note su alcuni giardini settecenteschi dei palazzi nobiliari palermitani. In Sessa Ettore, Mauro Eliana (a cura di). Il valore della classicità nella cultura del giardino e del paesaggio. Palermo: Grafill, pp 403-4I7.

Santagati Luigi (2006). Viabilità e topografia della Sicilia antica. Caltanissetta: Paruzzo.

Scibilia Federica, Scibilia Nunzio (2013). Pietro Scibilia ingegnere architetto (I 889-1971). Roma:Aracne.

Spatafora Francesca (2003). Nuovi dati sulla topografia di Palermo. In Quarte giornate internazionali di studi sull'Area Elima, Erice |-4 dicembre 2000, Pisa: Scuola Normale Superiore. pp. | | 75- | | 88.

Storchi Paolo (20 I3). Per l'identificazione dell'anfiteatro di Palermo romana e considerazioni su altri edifici per spettacolo. In Atlante tematico di Topografia Antica, n.23, 2013, pp. 6I-7I.

Storchi Paolo (20 I3). Palermo romana: trovato l'anfiteatro? In Archeologia viva, set-ott 20 I3, pp. 6I-7I.

Storchi Paolo (20|4). Topographical reconstruction of ancient Palermo: a note on its buildings for public spectacles and their relation with the Roman-period civic planning. In Proceedings of Landscape Archaeology Conference (LAC), Roma, I7-20 sett. 2014, pp. I-9. <http://lac20 | 4proceedings.nl/article/view/80>.

Tamburello Ida (1998). Palermo punico-romana. La storia dei rinvenimenti archeologici. Palermo: Luxograph.

Trevisan Camillo (1998). Sullo schema geometrico costruttivo degli anfiteatri romani: gli esempi del Colosseo e dell'Arena di Verona. In Disegnare idee immagini, n. I8/19, 1998, pp. I17-132.

Vesco Maurizio (20 I0). Un cantiere barocco a Palermo: il palazzo di Diego Aragona e Tagliavia, duca di Terranova. In Lexicon, n. I0/II, 2010, pp. 98-102.

\section{Authors}

Gian Marco Girgenti, Università degli Studi di Palermo, gianmarco.girgenti@unipa.it Claudia Tarantino, Università degli Studi di Palermo, claudia.tarantino92@gmail.com

To cite this chapter. Girgenti Gian Marco, Tarantino Claudia (2020). Connessioni e stratificazioni della forma urbana. Le tracce degli anfiteatri romani e le loro risignificazioni/Connections and stratifications of the urban shape. The traces of the Roman anphitheaters in their metamorphoses. In Arena A., Arena M., Brandolino R.G., Colistra D., Ginex G., Mediati D., Nucifora S., Raffa P. (a cura di). Connettere. Un disegno per annodare e tessere. Atti del $42^{\circ}$ Convegno Internazionale dei Docenti delle Discipline della Rappresentazione/Connecting. Drawing for weaving relationships. Proceedings of the 42th International Conference of Representation Disciplines Teachers. Milano: FrancoAngeli, pp. I I 83-1 204. 